\title{
Stress field sensitivity analysis in a sedimentary sequence of the Alpine foreland, northern Switzerland
}

\author{
T. Hergert ${ }^{1, *}$, O. Heidbach ${ }^{2}$, K. Reiter ${ }^{2,3, *}$, S. B. Giger ${ }^{4}$, and P. Marschall ${ }^{4}$ \\ ${ }^{1}$ Karlsruhe Institute of Technology, Institute of Applied Geosciences, Adenauerring 20b, 76131 Karlsruhe, Germany \\ ${ }^{2}$ GFZ German Research Centre for Geosciences, Section 2.6 Seismic Hazard and Stress Field, Telegrafenberg, \\ 14473 Potsdam, Germany \\ ${ }^{3}$ University of Potsdam, Inst. of Earth and Environmental Science, Karl-Liebknecht-Str. 24-25, \\ 14476 Potsdam-Golm, Germany \\ ${ }^{4}$ NAGRA, National Cooperative for the Disposal of Radioactive Waste, 5430 Wettingen, Switzerland \\ "now at: TU Darmstadt, Institute of Applied Geosciences, Schnittspahnstr. 9, 64287 Darmstadt, Germany
}

Correspondence to: T. Hergert (hergert@geo.tu-darmstadt.de)

Received: 3 February 2015 - Published in Solid Earth Discuss.: 19 February 2015

Revised: 23 April 2015 - Accepted: 28 April 2015 - Published: 21 May 2015

\begin{abstract}
The stress field at depth is a relevant parameter for the design of subsurface constructions and reservoir management. Yet the distortion of the regional stress field due to local-scale features such as sedimentary and tectonic structures or topography is often poorly constrained. We conduct a stress sensitivity analysis using 3-D numerical geomechanical modelling with an elasto-plastic material law to explore the impact of such site-specific features on the stress field in a sedimentary sequence of the Swiss Alpine foreland. The model's dimensions are $14 \times 14 \times 3 \mathrm{~km}^{3}$ and it contains 10 units with different mechanical properties, intersected by two regional fault zones. An initial stress state is established involving a semi-empirical relationship between the ratio of horizontal to vertical stress and the overconsolidation ratio of argillaceous sediments. The model results indicate that local topography can affect the stress field significantly to depths greater than the relief contrasts at the surface, especially in conjunction with horizontal tectonic loading. The complexity and frictional properties of faults are also relevant. The greatest variability of the stress field arises across the different sedimentary units. Stress magnitudes and stress anisotropy are much larger in stiffer formations such as massive limestones than in softer argillaceous formations. The stiffer formations essentially carry the load of the far-field forces and are therefore more sensitive to changes of the boundary conditions. This general characteristic of stress distribution in the stiff and soft formations is broadly maintained also with
\end{abstract}

progressive loading towards the plastic limit. The stress field in argillaceous sediments within a stack of formations with strongly contrasting mechanical properties like in the Alpine foreland appears to be relatively insensitive to changes in the tectonic boundary conditions and is largely controlled by the maximum stiffness contrast with respect to the load-bearing formations.

\section{Introduction}

Knowledge of the in situ stress in the subsurface and its local variability is a critical issue for academic questions and application in industry likewise (Fuchs and Müller, 2001; Hergert and Heidbach, 2011; Tingay et al., 2005). In particular for geotechnical projects such as tunnelling, boreholes or reservoir management, knowledge of the stress state is required in order to plan safe and sustainable underground operations (Altmann et al., 2014; Moeck et al., 2009; Zoback, 2010).

The stress field in the upper crust can vary strongly on a local scale due to topography, faults and variable properties of formations. Savage and Morin (2002) showed that topography can cause a highly variable stress field up to polarity reversals of the principal stresses. Examples for stress perturbations due to faults have been compiled by Barton and Zoback (1994) and Yale (2003). Warpinski (1989) showed on the basis of a large number of hydraulic fracturing data 
that linear interpolation of stress magnitudes across different lithologies can result in erroneous estimates. Using a 2-D generic numerical geomechanical model, Roche et al. (2013) showed that the impact of formations on the stress field can be significant. This is also shown by Gunzburer and Magnenet (2014) who used stress data to invert the mechanical properties of weak layers in the sediment layers of the Paris basin.

Constraining the stress field at local scale in northern Switzerland is of particular interest for the evaluation of identified potential geological siting areas in the context of radioactive waste disposal (Nagra, 2008). The siting areas are characterized by moderate local topography (approximately up to 300 to $400 \mathrm{~m}$ of difference in relief). The candidate host rocks are Mesozoic argillaceous sediments, which alternate with Mesozoic clastics, marls, carbonates, and evaporites. For high-level waste, the Lower Dogger-Opalinus Clay is the anticipated host rock.

Information on the stress field is often very sparse and incomplete, especially at depths relevant for energy resources or subsurface constructions (i.e. a few hundred metres to kilometres). Stress magnitude data for these depths are available in exceptional cases only but the orientation of maximum horizontal stress $\left(S_{\mathrm{H}}\right)$ and possibly the stress regime may be constrained at a few locations within the area of interest. Such data are systematically compiled in the database of the World Stress Map project using various stress indicators (Heidbach et al., 2010; Sperner et al., 2003; Zoback, 1992). However, given the sparse data coverage, the role of topography, faults and layered sedimentary formations on local stress variability can hardly be assessed based on available stress data alone (Heidbach et al., 2007). Thus, 3-D numerical geomechanical models are essential to assess spatially all components of the stress tensor (Fischer and Henk, 2013; Henk, 2008; Reiter and Heidbach, 2014).

In this study we present a 3-D numerical geomechanical model based on semi-generic and simplified geological structures of a potential waste disposal site, the siting area Nördlich Lägern (NL), to estimate its contemporary stress state. In a first step we calibrate a base model with in situ stress data to come up with a best-fit description of the stress field. To investigate the effect of topography, geometry and frictional properties of regional faults as well as the impact of geomechanical properties within the sedimentary sequence on the stress field, we conduct a sensitivity analysis with respect to the base model. The objective of this study is to explore the relative impact of parameter variations on the 3-D local stress field rather than a precise estimation of the absolute stress state. In particular we focus on the stress variability within the Opalinus Clay since this is the anticipated host rock for the repository.

\section{Model setup}

\subsection{Tectonic setting and stress field of northern Switzerland}

The area under consideration is located in northern Switzerland within the northern Alpine foreland. The pre-Mesozoic basement is exposed in the Black Forest in Southwest Germany (Fig. 1a). In northern Switzerland, deep boreholes, seismic and gravity data have shown that the basement is segmented by ENE-WSW striking Permo-Carboniferous Troughs (PCT) which formed during the pre-Alpine Variscan orogeny (Diebold et al., 1991; Nagra, 2008).

At the end of the Mesozoic period towards the Early Cenozoic (Paleocene), central northern Switzerland became affected by the far-field consequences of the Alpine orogeny (e.g. Schmid et al., 1996). Reconstructions of the PaleoceneEocene northern foredeep coastline suggest that the area was located on top of a forebulge zone, eventually leading to uplift and erosion during Paleocene to Early Eocene times (Sinclair and Allen, 1992; Kempf and Pfiffner, 2004). From early Miocene onwards uplift of the Black Forest massif in conjunction with the formation of the Alpine flexural Molasse Basin led to extensional reactivation of pre-existing basement faults (Diebold and Noack, 1997). The gentle dip of Mesozoic sediments to the south (Fig. 1b) is attributed to the cumulative effects of the foreland flexure and the uplift of the Black Forest massif.

In late Miocene age the Alpine deformation front propagated into the northern foreland, resulting in the formation of the Jura mountain range. The northward propagation of the deformation front is widely accepted to have occurred along a decollement horizon in the Middle to Upper Triassic evaporites, and the Jura mountain range hence represents a thin-skinned foreland fold-and-thrust belt (Laubscher, 1972; Sommaruga, 1997). It has also been noted that the location of major thin-skinned thrust faults roughly coincides with underlying pre-existing basement faults, and this was interpreted as a passive structural inheritance (Laubscher, 1986; Diebold and Noack, 1997). However, some authors have also reported evidence for a post-Pliocene compressive to transpressional thick-skinned reactivation of similar deep-seated faults in the Alpine foreland (Ustaszewski and Schmid, 2007; Madritsch et al., 2008).

The present-day stress map of northern Switzerland is displayed in Fig. 1 and shows 128 data records with a mean $S_{\mathrm{H}}$ orientation of $160 \pm 20^{\circ}$ (Heidbach and Reinecker, 2013). The $S_{\mathrm{H}}$ orientation rotates by $20-30^{\circ}$ counter-clockwise from approximately north-south in the Lake Constance area to NNW-SSE in the Basel area. This is in agreement with the regional trend of rather uniform $S_{\mathrm{H}}$ orientation perpendicular to the Alpine chain and isobaths of the Moho (Ziegler and Dèzes, 2006) as found by Reinecker et al. (2010) and Heidbach and Reinecker (2013). Furthermore, Fig. 1 shows the location of the three boreholes Basel, Benken and Schlattingen, 


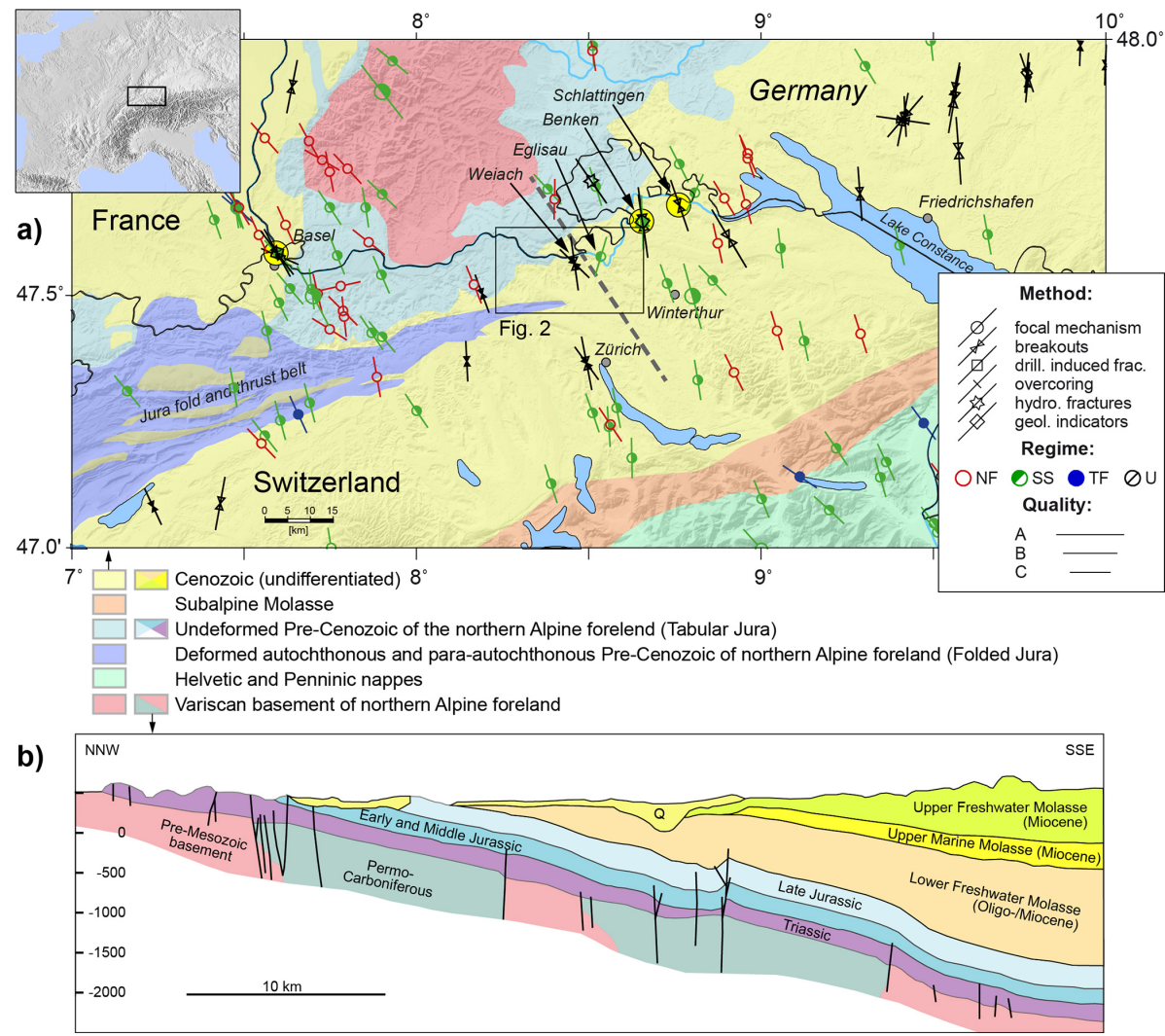

Figure 1. General geological setting of the model area in northern Switzerland. (a) Main geological units (after Nagra, 2008) and 128 A-C quality data records of the revised World Stress Map database release 2008 (Heidbach and Reinecker, 2013; Heidbach et al., 2008). Bars indicate orientation of maximum horizontal stress $S_{\mathrm{H}}$, symbols indicate type of stress indicator and colours relate to tectonic regime with red for normal faulting (NF), green for strike-slip faulting (SS), blue for thrust faulting (TF), and black for unknown tectonic regime (U). Yellow circles show the three locations where stress magnitude data are available (Basel, Benken, Schlattingen). Black dashed line denotes the location of the cross section in (b). (b) Generalized geological cross section through the main lithological layers in the northern Alpine foreland, modified after Mazurek et al. (2006).

where magnitude data of the minimum horizontal stress $S_{\mathrm{h}}$ exist at greater depth. However, measurements are not continuous across all lithological horizons (Nagra, 1999; Klee, 2012; Valley and Evans, 2015) and thus, the variability of in situ stress is not fully captured by measurements.

\subsection{Location of the model area}

The model extends over an area of $14 \times 14 \mathrm{~km}^{2}$ and is situated approximately $20 \mathrm{~km}$ north of Zürich (Fig. 1a). It broadly covers the geological siting area Nördlich Lägern (Fig. 2), which is investigated by the National Cooperative for the Disposal of Radioactive Waste as a candidate site for a repository (Nagra, 2008). The gentle southern dip of the Mesozoic formations in combination with local topography variation of up to $300 \mathrm{~m}$ (Fig. 2) leads to variable burial depth for Mesozoic sediments. The mid-depth of the 100 to $120 \mathrm{~m}$ thick Opalinus Clay formation is hence between 500 and $860 \mathrm{~m}$ below ground level in the siting area and becomes shallower to the northwest of the model area (up to $100 \mathrm{~m}$ below ground level).

Miocene shortening in the model area was moderate and is estimated to a maximum of $200 \mathrm{~m}$ from balanced cross sections (Malz et al., 2014; Nagra, 2014a). The dominant compressive structures in the model area which accommodated the late Miocene south-north directed shortening are the Siglistorf Fault (SF) and the Stadel-Irchel Fault (SIF) (Fig. 2). These two gently south-dipping and ENE-WSW striking faults with a clear reverse component at the level of the Mesozoic sediments are developed approximately above steeper pre-Mesozoic basement faults with similar strike and bounding the PCT. The southern bounding fault of the PCT is rather well constrained from seismics and known as the Baden-Irchel-Herdern lineament (BIH). But in contrast to the SIF, it is interpreted to dip to the north (Nagra, 2008). The geometrical and kinematic relationship between the reverse faults of Miocene age and the older normal faults of the PCT is subject of ongoing investigations (e.g. Malz et al., 2014). 


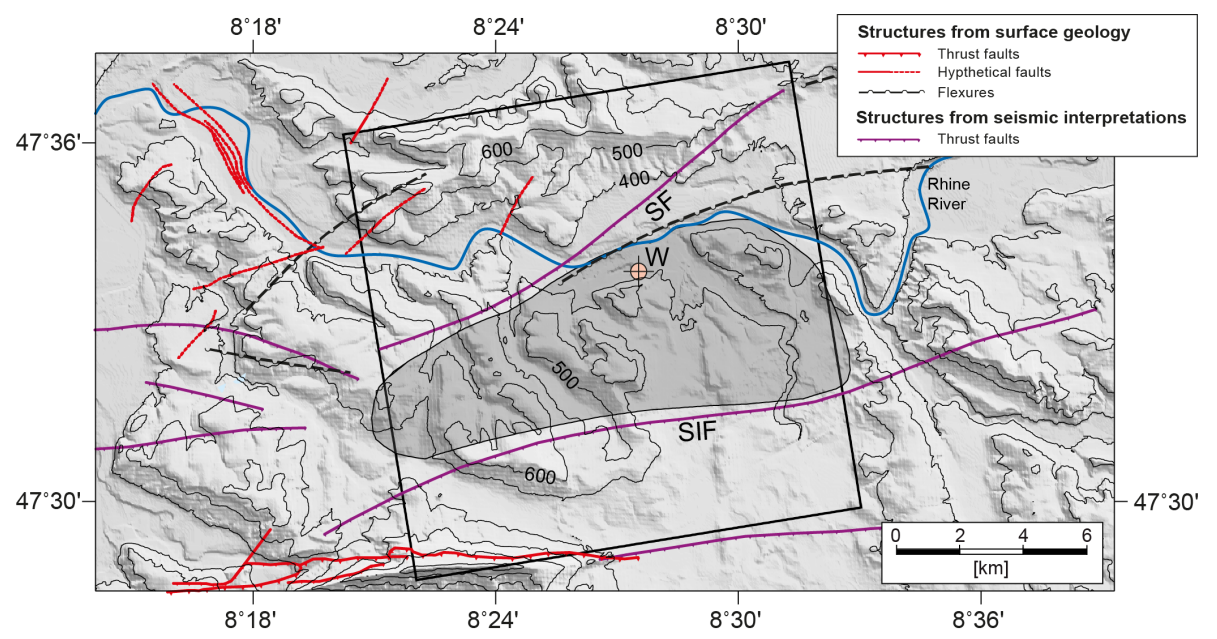

Figure 2. Tectonic map showing the location and extent of the model area $\left(14 \times 14 \mathrm{~km}^{2}\right.$, black square). Stadel-Irchel Fault (SIF) and the Siglistorf Fault (SF) are integrated in the model. The Weiach well (W) is indicated within the siting area Nördlich Lägern (grey shaded area). Topography contours (thin black lines) in metres above sea level; note the variation of elevation of approximately $300 \mathrm{~m}$ within the model area. After Nagra (2008).

The Weiach borehole (Matter et al., 1988) is located roughly in the geographic centre of the model (Fig. 2) and the only direct source of stress information at greater depth. From analysis of borehole breakouts to a depth of approximately $2500 \mathrm{~m}$ below ground level the $S_{\mathrm{H}}$ orientation was interpreted to strike approximately $172^{\circ} \mathrm{N}$ (Heidbach and Reinecker, 2013), which is in good agreement with the findings in regional wells (Fig. 1a). In the Upper Dogger and Lower Malm sections at the Weiach borehole, the $S_{\mathrm{H}}$ azimuth was found to deviate from the dominant value in the Mesozoic and Paleozoic formations, striking at $134^{\circ} \mathrm{N}$.

The eastern and western model boundaries are oriented $170^{\circ} \mathrm{N}$ (Fig. 2), which is approximately parallel to the dominant interpreted orientation of $S_{\mathrm{H}}$ and approximately perpendicular to the ENE-WSW trending major fault structures. The top of the model is the topography and the base of the model is at $2500 \mathrm{~m}$ below sea level.

\subsection{Model assumptions and workflow}

Figure 3 gives an overview of the model setup and workflow. The model includes structural information such as geometries of faults and lithological horizons. Ten individual formations are considered which are characterized by their respective rock properties (density, elastic and plastic parameters; Table 1), hereafter referred to as geomechanical units. Each geomechanical unit is considered as homogeneous with isotropic mechanical properties. The faults are represented as contact surfaces that are not allowed to penetrate or separate from each other and on which slip is possible according to Coulomb's friction law, which relates the critical shear stress for slip to the coefficient of static friction, the normal stress acting on the surface and cohesion, which we assume as zero.

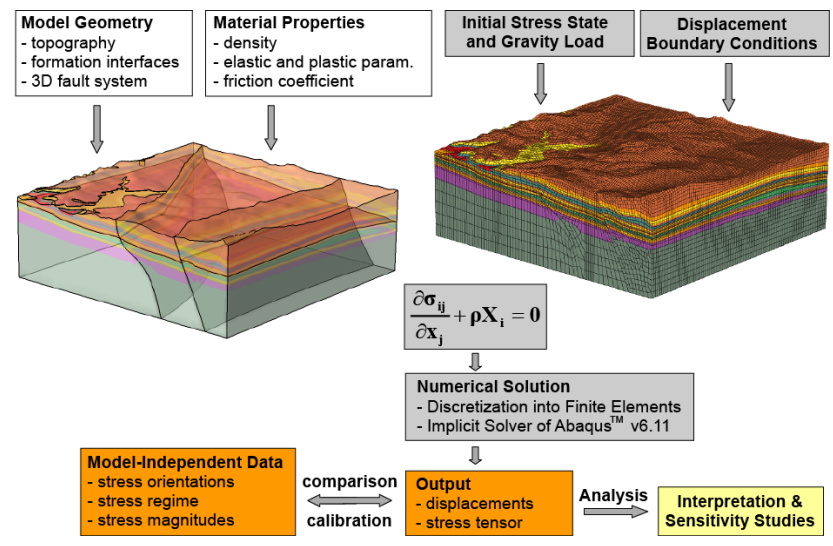

Figure 3. General workflow. Left figure: 3-D view of the model structure. Right figure: discretized model volume. White boxes: assembly of model geometry, rock properties and the 3-D fault system. Grey boxes: gravity, initial stress field and displacement boundary conditions are determined and applied; numerical solution. The partial differential equations of the equilibrium of forces in 3-D are solved using the finite element method ( $\sigma_{i j}$ stress tensor, $x_{j}$ Cartesian coordinates, $\rho$ density, and $X_{i}$ body forces). Orange boxes: model results are compared to model-independent data. Yellow box: once the fit to the model-independent observations is acceptable the model results are interpreted and analysed. This includes a sensitivity analysis with respect to the uncertainties of the model parameters.

An initial stress state representing a reference stress state is established using semi-empirical relationships between the vertical to horizontal stress ratio and the overconsolidation ratio (OCR) of argillaceous sediments, namely for the Opalinus Clay (Sect. 2.5). Displacement boundary conditions introduce tectonic stresses from the far field and control defor- 
Table 1. Lithological and grouped geomechanical units with mechanical properties. Estimation of density values $(\rho)$ are based on Matter et al. (1988), elastic properties (Young's Modulus $E$ and Poisson's ratio $v$ ) are based on Nagra (2001) and Mohr-Coulomb strength parameters (friction angle $\phi$ and Cohesion $C$ ) are estimated from Böhringer et al. (1990) and Nagra (2014b).

\begin{tabular}{|c|c|c|c|c|c|c|c|c|}
\hline & Lithostratigraphy & $\begin{array}{l}\text { Thickness at } \\
\text { Weiach [m] }\end{array}$ & Model unit & {$\left[\mathrm{g} \mathrm{cm}^{\rho}{ }^{\rho}\right]$} & $\begin{array}{r}E \\
{[\mathrm{GPa}]}\end{array}$ & $v$ & $\begin{array}{r}\phi \\
{\left[{ }^{\circ}\right]}\end{array}$ & $\begin{array}{r}C \\
{[\mathrm{MPa}]}\end{array}$ \\
\hline 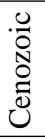 & $\begin{array}{l}\text { Quaternary } \\
\text { OSM/OMM } \\
\text { USM/Bohnerz Fm. }\end{array}$ & $\begin{array}{l}37 \\
- \\
149\end{array}$ & $\begin{array}{l}\text { Quaternary cover (11) } \\
\text { Molasse (10) }\end{array}$ & $\begin{array}{l}2.35 \\
2.35\end{array}$ & $\begin{array}{l}15 \\
15\end{array}$ & $\begin{array}{l}0.29 \\
0.29\end{array}$ & $\begin{array}{l}38 \\
38\end{array}$ & $\begin{array}{l}10 \\
10\end{array}$ \\
\hline$\frac{\Xi}{\sum^{\pi}}$ & $\begin{array}{l}\text { Felsenkalke to } \\
\text { Villigen Fm. } \\
\text { Wildegg-Fm. } \\
\text { (incl. Effingen Member) }\end{array}$ & $\begin{array}{l}202 \\
87\end{array}$ & $\begin{array}{l}\text { Upper Malm (9) } \\
\text { Wildegg Fm. (8) }\end{array}$ & 2.65 & 40 & 0.25 & 50 & 20 \\
\hline $\begin{array}{l}\dot{D} \\
00 \\
00 \\
\circ \\
0\end{array}$ & $\begin{array}{l}\text { Wutach Fm. to } \\
\text { Murchisonae-Oolith Fm. } \\
\text { Opalinus Clay }\end{array}$ & $\begin{array}{l}77 \\
112\end{array}$ & $\begin{array}{l}\text { Upper Dogger (7) } \\
\text { Opalinus Clay (6) }\end{array}$ & $\begin{array}{l}2.55 \\
2.50\end{array}$ & 10 & $\begin{array}{l}0.27 \\
0.29\end{array}$ & 30 & 4 \\
\hline 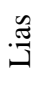 & $\begin{array}{l}\text { Upper and Lower Lias } \\
\text { Upper Mittelkeuper }\end{array}$ & 64 & $\begin{array}{l}\text { Lias and Upper } \\
\text { Mittelkeuper (5) }\end{array}$ & 2.45 & 15 & 0.25 & 30 & 8 \\
\hline 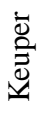 & $\begin{array}{l}\text { Gipskeuper } \\
\text { (incl. Lettenkohle) }\end{array}$ & 83 & Gipskeuper (4) & 2.70 & 20 & 0.25 & 34 & 28 \\
\hline 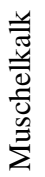 & $\begin{array}{l}\text { Upper Muschelkalk } \\
\text { Middle Muschelkalk } \\
\text { Lower Muschelkalk }\end{array}$ & $\begin{array}{l}69 \\
57 \\
37\end{array}$ & $\begin{array}{l}\text { Upper Muschelkalk (3) } \\
\text { Middle and Lower } \\
\text { Muschelkalk (2) }\end{array}$ & $\begin{array}{l}2.65 \\
2.65\end{array}$ & $\begin{array}{l}40 \\
20\end{array}$ & $\begin{array}{l}0.25 \\
0.25\end{array}$ & $\begin{array}{l}45 \\
40\end{array}$ & $\begin{array}{l}23 \\
20\end{array}$ \\
\hline & Buntsandstein & 10 & & & & & & \\
\hline 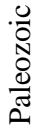 & $\begin{array}{l}\text { Permo-Carboniferous/ } \\
\text { Pre-Mesozoic basement }\end{array}$ & $>1490$ & $\begin{array}{l}\text { Pre-Mesozoic } \\
\text { Basement (1) }\end{array}$ & 2.60 & 30 & 0.25 & 40 & 30 \\
\hline
\end{tabular}

mation and stress in the model's interior along with gravity. The equilibrium of forces is computed numerically using the finite element solver Abaqus (Dassault Systèmes, 2011). The basic output of the model is the 3-D displacement and stress field which has to be compared to model-independent data.

\subsection{Model geometry and rock properties}

The geological model used as a basis for the geomechanical model is generated from field mapping, shallow and deep boreholes and depth-converted 2-D seismic sections in northern Switzerland (see Nagra, 2008). The lithostratigraphic formations of the geological model are grouped into 10 model units with different geomechanical properties (Table 1). Criteria for consideration of individual geomechanical units are sufficiently large thickness for numerical feasibility and sufficiently large contrast in mechanical properties of adjacent lithostratigraphic formations. A thick interval in excess of $1000 \mathrm{~m}$ of PCT sediments was encountered at the Weiach well, but because of poor seismic reflectivity below the Mesozoic cover sediments, the geometry of the PCT is not well constrained. Therefore, no distinction is made between pre-Mesozoic basement rocks and PCT sediments.

Complex fault structures interpreted from geological cross sections (Fig. 1b) are strongly simplified when adopted in 3-D geological models. They are further simplified for the numerical geomechanical model due to uncertainties in the structural information and the technically feasible resolution of the finite element mesh. The Siglistorf Fault (SF) in the north of the model area and the Stadel-Irchel Fault (SIF) in the south are incorporated as the two major, east-west striking faults. The SF is generally interpreted to root in the evaporites of the Middle Muschelkalk, and therefore represents an example of thin-skinned tectonics. However, a direct relationship with a pre-Mesozoic normal fault at greater depth and hence thick-skinned tectonics cannot be excluded. Therefore, the SF in the finite element model is discretized as a single fault surface, extending the well-constrained reverse fault at the level of the Mesozoic sediments to greater depth with the more speculative, pre-Mesozoic basement fault in- 


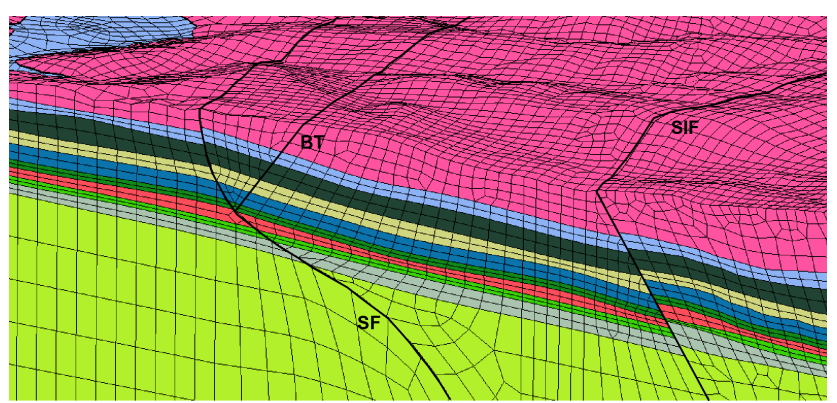

Figure 4. Discretized model volume viewed from southwest. Thick black lines indicate the faults that are implemented as contact surfaces with Coulomb friction. Colour-coded are the individual geomechanical units and BT denotes back-thrust.

terpreted from seismics (i.e. the northern boundary fault of the PCT) (Fig. 4). As will be described in Sect. 4.3, the steeper fault branch below the Mesozoic sediments can effectively be disconnected by assigning a very high friction coefficient. This is the chosen technique to investigate the effect of thin-skinned versus thick-skinned tectonics on the stress field.

To investigate the effect of a more complex fault structure on the local stress field, an antithetic back-thrust to the SF, dipping $50^{\circ}$ to the north, is also implemented in the model (Model GR in Sect. 4). It is assumed that this subsidiary fault strikes parallel to SF and roots at the Keuper-Gipskeuper interface (Fig. 4).

The SIF consists of a number of compressive, mainly south-dipping fault structures and is geometrically related to the prominent BIH. For the geomechanical model, this complex structure is highly simplified as a single south-dipping fault with a net reverse faulting offset (Fig. 4). Both, the SF and the SIF faults are extended to the base of the geomechanical model ( $2500 \mathrm{~m}$ below sea level). The geomechanical model units are characterized by their mechanical rock properties. Representative values for density $\rho$ and elastoplastic parameters (Young's modulus $E$, Poisson's ratio $v$, friction angle $\phi$ and cohesion $C$ ) are assigned to each of the units (Table 1). The mechanical parameters were estimated on the basis of geophysical logs and geomechanical test results. We also consider a homogeneous model in order to assess the influence of topography and faults in the absence of the stress perturbations arising from spatially variable rock properties. The effective coefficient of friction on the faults is assumed as $\mu^{\prime}=0.2$. While this is a low value even at high pore fluid pressure, which is not explicitly accounted for, it represents a case in which the stress-perturbing influence of the faults is maximized and the blocks are widely decoupled from each other. Additionally, an effective coefficient of friction of $\mu^{\prime}=1.0$ is tested to consider the case of strong coupling of the blocks.

The model volume is discretized into $\sim 272000$ hexahedron elements with linear approximation function (Fig. 4), where each of the geomechanical units is comprised of at least two element layers. The spatial resolution in terms of finite element size is $\sim 100-200 \mathrm{~m}$ in the horizontal direction and $\sim 20-80 \mathrm{~m}$ in the vertical direction.

\subsection{Initial stress state, gravity, boundary conditions and model calibration}

\subsubsection{Definition of initial stress}

The initial stress state of the model considers no horizontal tectonic loading and is in equilibrium with gravity forces. For normally consolidated clays or clay-rich soils, the horizontal to vertical effective stress ratio $\left(K^{\prime}\right)$ is generally approximated by $S_{\mathrm{h}}^{\prime} / S_{\mathrm{V}}^{\prime} \approx 1-\sin \left(\phi^{\prime}\right)$ (Jáky, 1944), where $S_{\mathrm{V}}$ is the vertical stress and $\phi^{\prime}$ is the effective friction angle. Empirical correlations have shown that the ratio $K^{\prime}$ of overconsolidated clays or shales during unloading (e.g. exhumation) are elevated with respect to values at identical depth during initial or normal loading (e.g. Brooker and Ireland, 1965). Mayne and Kulhawy (1982) suggested to extend the stress ratio relationship for normally consolidated clays to overconsolidated clays or shales by taking into account the overconsolidation ratio (OCR), such that the effective stress ratio $K^{\prime}$ becomes

$$
K^{\prime}=\left(1-\sin \varphi^{\prime}\right) \cdot \mathrm{OCR}^{\sin \varphi^{\prime}},
$$

where OCR is the ratio of the maximum effective overburden stress experienced during its geologic history $\left(S_{\mathrm{VC}}^{\prime}\right)$ and the present effective overburden stress $\left(S_{\mathrm{V}}^{\prime}\right)$. $S_{\mathrm{VC}}^{\prime}$ can be estimated e.g. by one-dimensional compression tests.

Applying Eq. (1) to Opalinus Clay by using $\phi^{\prime}=25^{\circ}$ and OCR values from three locations in northern Switzerland sampled at different depths, the depth-dependent effective stress ratio $K^{\prime}$ may then be approximated as (Giger and Marschall, 2014)

$K^{\prime}=0.58 \cdot\left(1+\frac{650}{z}\right)^{0.42}$,

where $z$ is the present depth in metres (Fig. 5a). Note that this relationship represents a depth-trend of effective stress ratios for a situation without any horizontal tectonic forces assuming validity of the semi-empirical approach formulated in Eq. (1). Since the numerical geomechanical model of this study uses total stress values, the effective stress ratio $K^{\prime}$ has to be converted into the total stress ratio $K$ by

$K=\frac{K^{\prime}\left(S_{\mathrm{V}}-P_{\mathrm{P}}\right)+P_{\mathrm{P}}}{S_{\mathrm{V}}}$,

where $S_{\mathrm{V}}$ is the vertical stress. Assuming hydrostatic pore fluid pressure $\left(P_{\mathrm{P}}\right)$ and a constant density of $\rho=2.5 \mathrm{~g} \mathrm{~cm}^{-3}$, Eq. (3) simplifies to

$K=0.6 \cdot K^{\prime}+0.4$. 


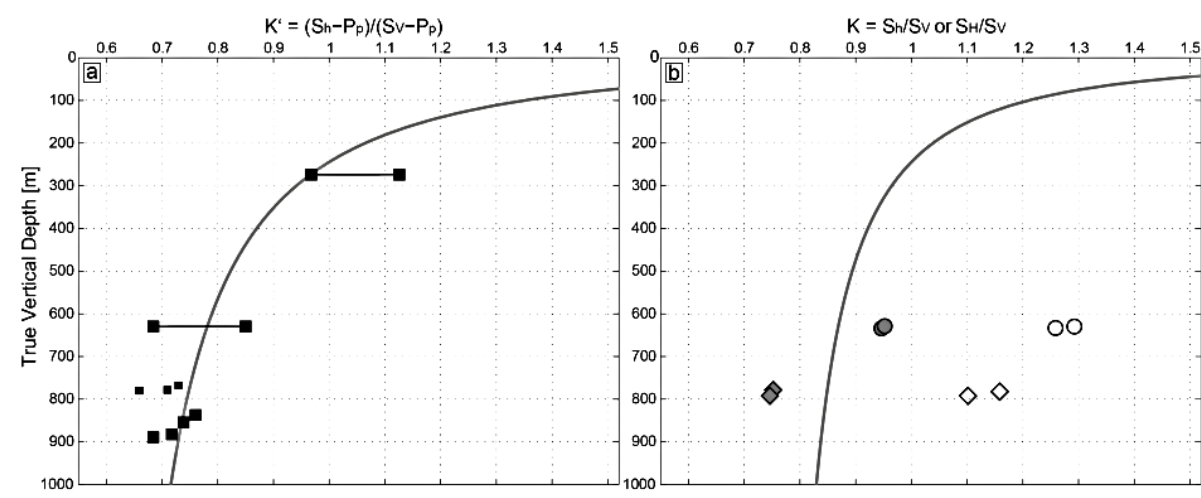

Figure 5. Depth-dependent stress ratio in Opalinus Clay in northern Switzerland. (a) Effective stress ratio $K^{\prime}$. Line shows calculated $K^{\prime}$ ratio for Opalinus Clay according to Eq. (2) and underlying database (large black squares) from the underground lab Mont Terri (present depth approximately $280 \mathrm{~m}, \mathrm{OCR} \approx 4)$, and the wells in Benken $(\sim 630 \mathrm{~m}, \mathrm{OCR} \approx 2)$ and Schlattingen $(\sim 900 \mathrm{~m}, \mathrm{OCR} \approx 1.7)$ assuming $\phi^{\prime}=25^{\circ}$. The small black squares represent data from Upper Dogger samples from Schlattingen with comparable clay mineral content as the Opalinus Clay. (b) Line shows calculated total stress ratio $K$ (Eq. 4), which is used to calibrate the initial stress state in Opalinus Clay in the model. Symbols show hydraulic fracturing data and represent the in situ stress state including tectonic loading (diamonds, Schlattingen (Klee, 2012); circles, Benken (Nagra, 1999); filled symbols, $S_{\mathrm{h}} / S_{\mathrm{V}}$; open symbols, $S_{\mathrm{H}} / S_{\mathrm{V}}$ ).

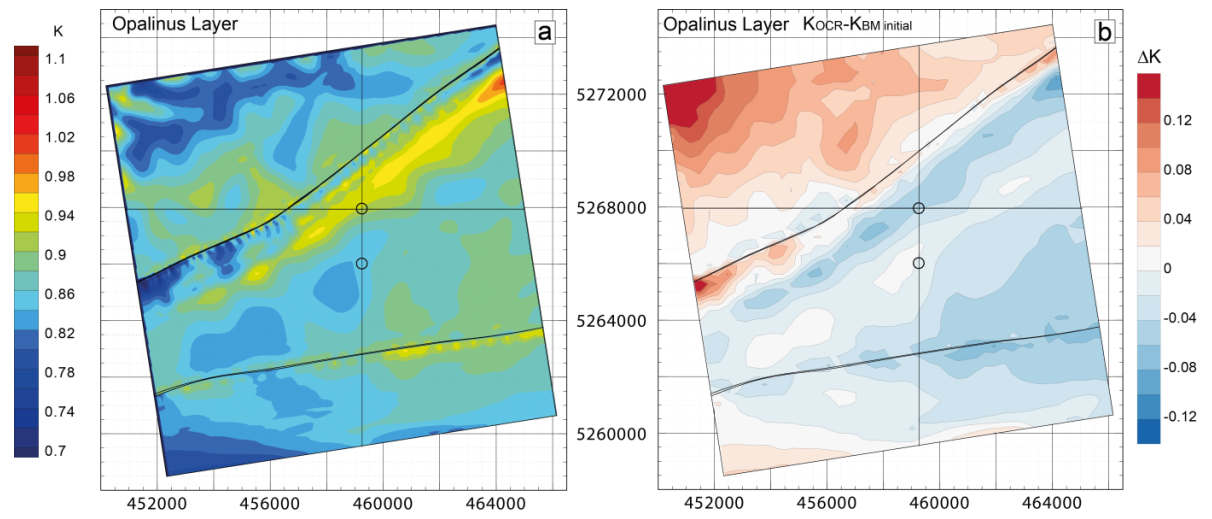

Figure 6. Initial stress state of the model at mid-depth of the Opalinus Clay formation (i.e. stress state without tectonic loading). (a) $K=$ $S_{\mathrm{h}} / S_{\mathrm{V}}$ of the initial stress. (b) Difference between the theoretical $K$ ratio from Eq. (4) and the initial stress state in the model as shown in (a). Small circles indicate the location of the two depth profiles displayed in Fig. 7c and f, the northern of which is the location of the Weiach well.

The resulting line in Fig. $5 \mathrm{~b}$ represents the total stress ratio $K$ for the calibration of the initial stress state in Opalinus Clay for the model. Also indicated in the same figure are stress ratios from hydraulic fracturing data from the Opalinus Clay in the boreholes of Benken (Nagra, 2001) and Schlattingen (Klee, 2012) in northern Switzerland (see Fig. 1 for location). The hydraulic fracturing data represent the in situ stress, i.e. the stress state including tectonic loading. The $K$ ratios from the $S_{\mathrm{h}}$ and $S_{\mathrm{H}}$ magnitudes at the Benken site plot to the right of the line, indicating that tectonic loading has led to horizontal stresses which are greater than expected by simple burial and unloading from the empirical relationship. Conversely, the $K$ ratio from the $S_{\mathrm{h}}$ magnitude from the Schlattingen well plots to the left of the line, indicating that tectonic unloading may have decreased the expected magnitude from the empirical relationship. This is consistent with the tectonic setting, as the Schlattingen well was drilled east of the Benken well and closer to the Hegau-Bodensee Graben (Nagra, 2014a).

\subsubsection{Implementation of initial stress}

Technically, the initial state of stress in the model is established by application of gravity on the model volume with its boundaries at the bottom and at the sides being fixed for displacements perpendicular to the model boundaries. During uniaxial compaction, the Poisson's ratio controls the horizontal stress and this mechanism is used to establish the stress state as defined in Eq. (4). In this first compaction step values for the Young's modulus $E$ are used as listed in Table 1 . The Poisson ratio values are $v=0.46$ for the argillaceous Opalinus Clay and Gipskeuper, $v=0.43$ for the pre- 

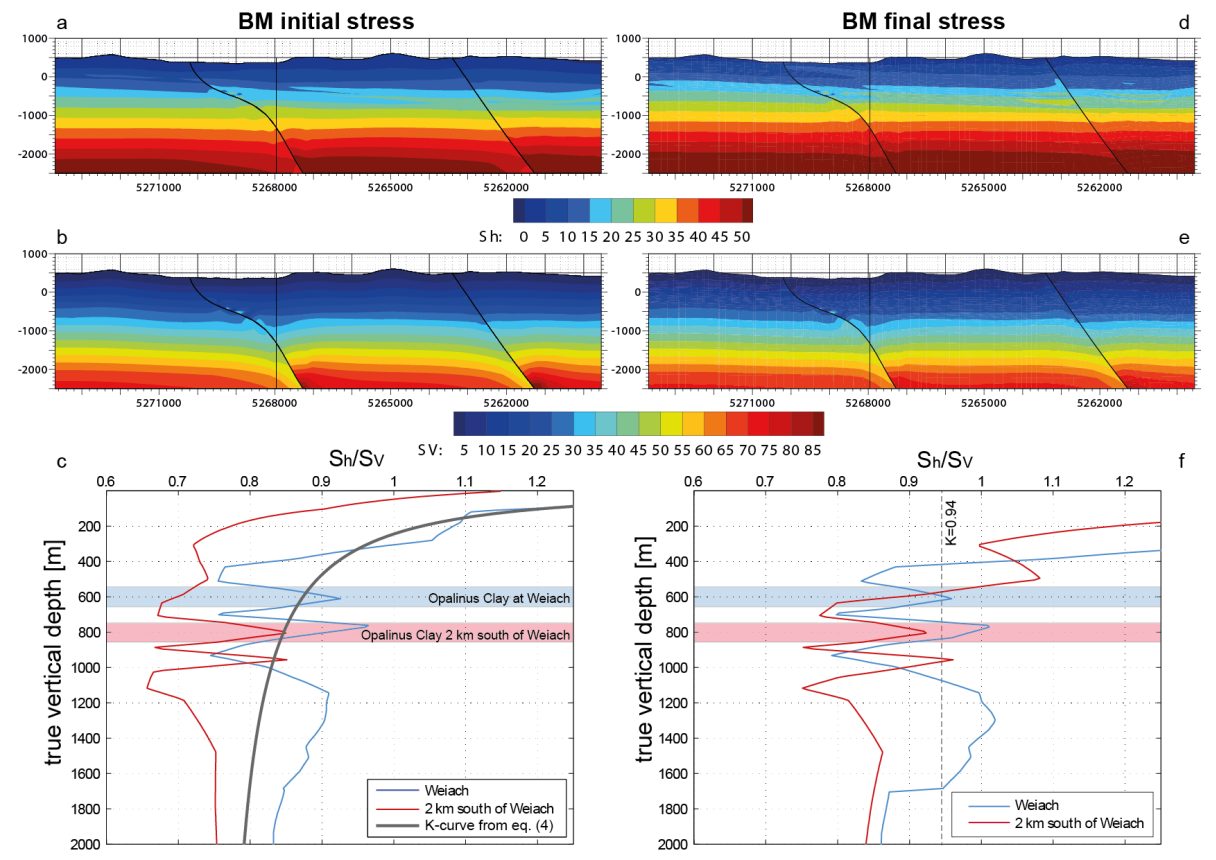

Figure 7. Magnitude of $S_{\mathrm{h}}$ (first row) and $S_{\mathrm{V}}$ (second row) on a north-south cross section through the Weiach well and $K=S_{\mathrm{h}} / S_{\mathrm{V}}$ on depth profiles at the location of the Weiach well and $2000 \mathrm{~m}$ south of it (third row) of initial (left column) and final stress (right column) of the base model (BM). Note that initial stress state is without tectonic boundary conditions and final stress state with tectonic boundary conditions applied. The grey line in (c) corresponds to the line in Fig. 5b, i.e. Eq. (4). Dashed line in (f) marks the value $K=0.94$, which is derived from hydraulic fracturing data at the Benken well in Opalinus Clay at a depth of $630 \mathrm{~m}$.

Mesozoic basement and $v=0.40$ for all other units. In an iterative approach the resulting stress state is used as an initial stress state in an undeformed model with the real Poisson ratios applied as stated in Table 1 to allow for rebalancing of displacements and to eventually come up with the initial stress state of the model that is in equilibrium with gravity.

Figure 6 shows the modelled initial $K$ ratio at the level of the Opalinus Clay (left) and the difference between the modelled initial $K$ ratio and the theoretical $K$ ratio from Eq. (4) (right) in map view. The $K$ ratio in the Opalinus Clay shows relatively small spatial variation between 0.8 and 0.95 in most of the model area. The deviation with respect to Eq. (4) is small except in the northwest of the model area, where the Opalinus Clay is between 150-250 m below the surface and thus strongly influenced by the prominent topography gradients in that area (Fig. 2). To the south of the SF the $K$ ratio is obviously influenced by this fault and thus there is no undisturbed, purely gravity-controlled stress state. In general, the modelled initial stress state fits the theoretical one in areas not influenced by faults or topography and is taken as the initial stress state of the model.

The initial stress state of the model is also extracted at two vertical profiles; one at the location of the Weiach well and the other $2000 \mathrm{~m}$ south of it (locations in Fig. 6, profiles in Fig. 7c and f). The $K$ ratio increases when approaching the surface. Over the depth range of the model, several jumps in $K$ ratio appear which are due to the different Poisson ra-

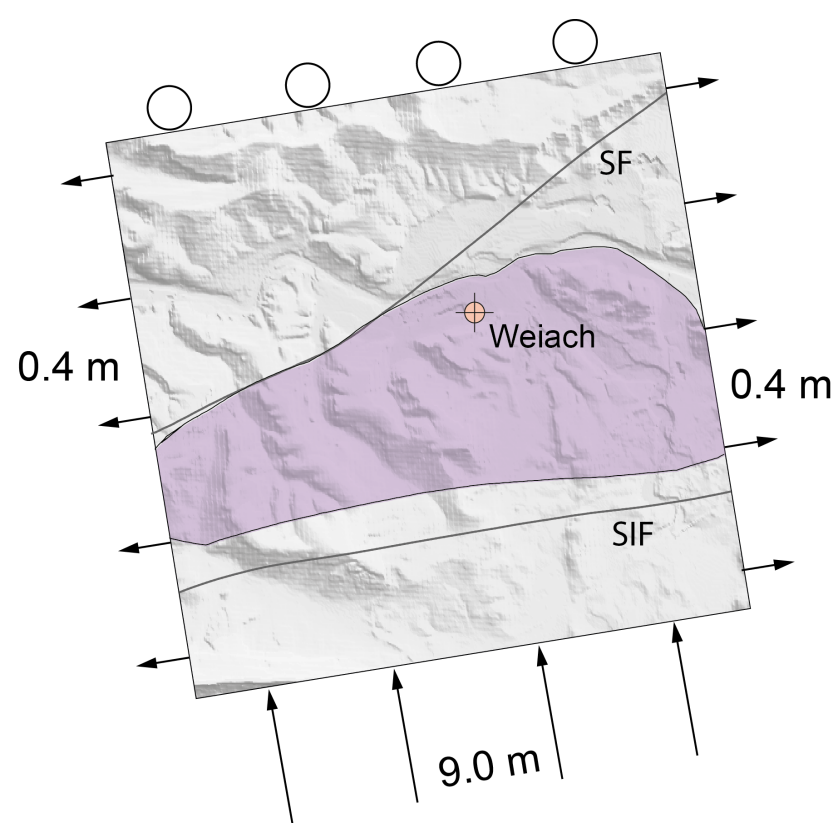

Figure 8. Displacement boundary conditions of model BM. Circles at the northern model boundary denote that no displacement perpendicular to the boundary is allowed, but parallel to it. Thin lines indicate the two implemented faults SF and SIF; purple area shows the extent of the siting area Nördlich Lägern. 
tios used for the geomechanical units in the compaction step (Fig. 7c). The argillaceous formations, which have high Poisson ratios in this step, show larger $K$ ratios than the other units which had a lower Poisson ratio. At the location of the Weiach well the mid-depth of the Opalinus Clay is encountered at $\sim 600 \mathrm{~m}$ below ground level where the $K$ ratio should be 0.875 according to Eq. (4). However, this site is in the zone apparently affected by the SF and therefore does not perfectly match the theoretical value that assumes no stress perturbations from faults (Figs. 6, 7c). The other profile located $2000 \mathrm{~m}$ further south between the SF and the SIF seems to be widely unaffected by these faults. Here, the Opalinus Clay is at $\sim 800 \mathrm{~m}$ depth and $K$ should be 0.845 according to Eq. (4). At this site, good agreement is obtained between the modelled and theoretical $K$ ratio.

\subsubsection{Final stress state and displacement boundary conditions}

After the initial stress state of the model is established and in equilibrium with gravity, horizontal displacement boundary conditions are applied at the vertical boundaries of the model to incorporate the tectonic stresses that result from the far-field forces (Fig. 8). These boundary conditions cannot be derived from geodetic observations as the interpreted displacement rates are very small and uncertainties large (Nagra, 2008). Thus, in order to integrate the available knowledge of south-north compression in the course of the Alpine orogenesis, the model is basically shortened in south-north direction and dilated in east-west direction (Fig. 8). To calibrate the amount of displacement, we fit the observed $S_{\mathrm{H}}$ orientation from the Weiach well (Heidbach and Reinecker, 2013), the overall transtensional tectonic stress regime in the basement of northern Switzerland (Heidbach and Reinecker, 2013) and the measured stress ratio $K=S_{\mathrm{h}} / S_{\mathrm{V}}=0.94$ from hydraulic fracturing in Opalinus Clay in the nearby Benken well (Nagra, 2001). For the latter value it is assumed that the stress magnitude at the level of the Opalinus Clay at the Benken borehole is a good proxy for the model area some $10 \mathrm{~km}$ to the southwest of this location.

Uniform displacement boundary conditions rather than stress boundary conditions are applied over the whole depth range of the sediments as the individual formations can be assumed to have experienced the same horizontal deformation. The best-fit boundary conditions are displacement of $9 \mathrm{~m}$ to the north at the southern model boundary perpendicular to it, while the boundaries in the west and east are pulled by $0.4 \mathrm{~m}$ each to the west and east, respectively; the northern model boundary is fixed for displacements perpendicular to the boundary. Displacements parallel to the model boundaries are allowed everywhere. Displacements at the bottom of the model are not allowed in vertical direction while horizontal displacements are permitted. The surface of the model is unconstrained. Due to the slightly rotated boundaries of the model with respect to north-south and east-west, the direc- tion of the exerted push is perpendicular to the compressive structures in the sedimentary cover. Results of the model calibration for this so-called base model (BM) are presented in the next section.

\subsubsection{Calibration results for the base model BM}

The prevailing $S_{\mathrm{H}}$ orientation of the stress field of model BM (final stress) is $170-175^{\circ}$ (Fig. 9b). In the vicinity of the SF $S_{\mathrm{H}}$ is slightly rotated counter-clockwise to $165-170^{\circ}$. No depth dependence of the $S_{\mathrm{H}}$ orientation is recognizable. The modelled $S_{\mathrm{H}}$ orientation agrees very well with the dominant data record from the Weiach well with a $S_{\mathrm{H}}$ orientation of $172^{\circ}$ between 560 and $2276 \mathrm{~m}$ drilled depth derived from $772 \mathrm{~m}$ borehole breakout length (Heidbach and Reinecker, 2013). The lower-quality data record from the Weiach well with a $S_{\mathrm{H}}$ orientation of $134^{\circ}$ represents the depth section 408-558 $\mathrm{m}$ drilled depth derived from $42 \mathrm{~m}$ borehole breakout length (a few in the Wildegg Formation and most of them in the Upper Dogger). This $S_{\mathrm{H}}$ orientation cannot be found in the model results. For comparison, the $S_{\mathrm{H}}$ orientation of the initial stress is shown in Fig. 9a. In the absence of displacement boundary conditions low horizontal differential stress permits local variations of the $S_{\mathrm{H}}$ orientation due to topography, faults and variable stiffness of the individual formations.

The tectonic regime of model BM shows transpression to compression close to the surface, visualized in terms of the Regime Stress Ratio (RSR) (Simpson, 1997; Fig. 9d). In the deeper sedimentary units including the Opalinus Clay a strike-slip regime prevails with a tendency towards transpression. The stratification is reflected by the tectonic regime with stiffer units being more compressive than softer units. Below the sedimentary column the tectonic regime becomes gradually more extensional and reaches almost transtension near the bottom of the model. For comparison, the tectonic regime of the initial stress (without displacement boundary conditions) is basically pure normal faulting with some local near-surface areas of thrust-faulting (Fig. 9c).

From earthquake focal mechanisms the dominant stress regime in the broader region is strike-slip to normal faulting. For the $1999 M=3.1$ earthquake near Eglisau at the eastern model boundary at $1-2 \mathrm{~km}$ depth a strike-slip focal mechanism solution has been determined (Deichmann et al., 2000; Fig. 1a).

Figure 7 shows the magnitudes of $S_{\mathrm{h}}$ and $S_{\mathrm{V}}$ of the initial and final stress states, respectively, on a north-south cross section and the $K$ ratio at the two depth profiles at the Weiach well and $2000 \mathrm{~m}$ south of it. At Weiach at $600 \mathrm{~m}$ true vertical depth the $K$ ratio of the final stress state is $K \cong 0.95$ and at $800 \mathrm{~m}$ true vertical depth at the location $2000 \mathrm{~m}$ south of the Weiach well $K \cong 0.93$, in agreement with $K=0.94$ derived from the Benken well data. The $S_{\mathrm{h}}$ magnitude increases from the initial stress to the final stress (Fig. 7a and d), whereas the $S_{\mathrm{V}}$ magnitude is essentially unchanged (Fig. $7 \mathrm{~b}$ and e). Thus, 


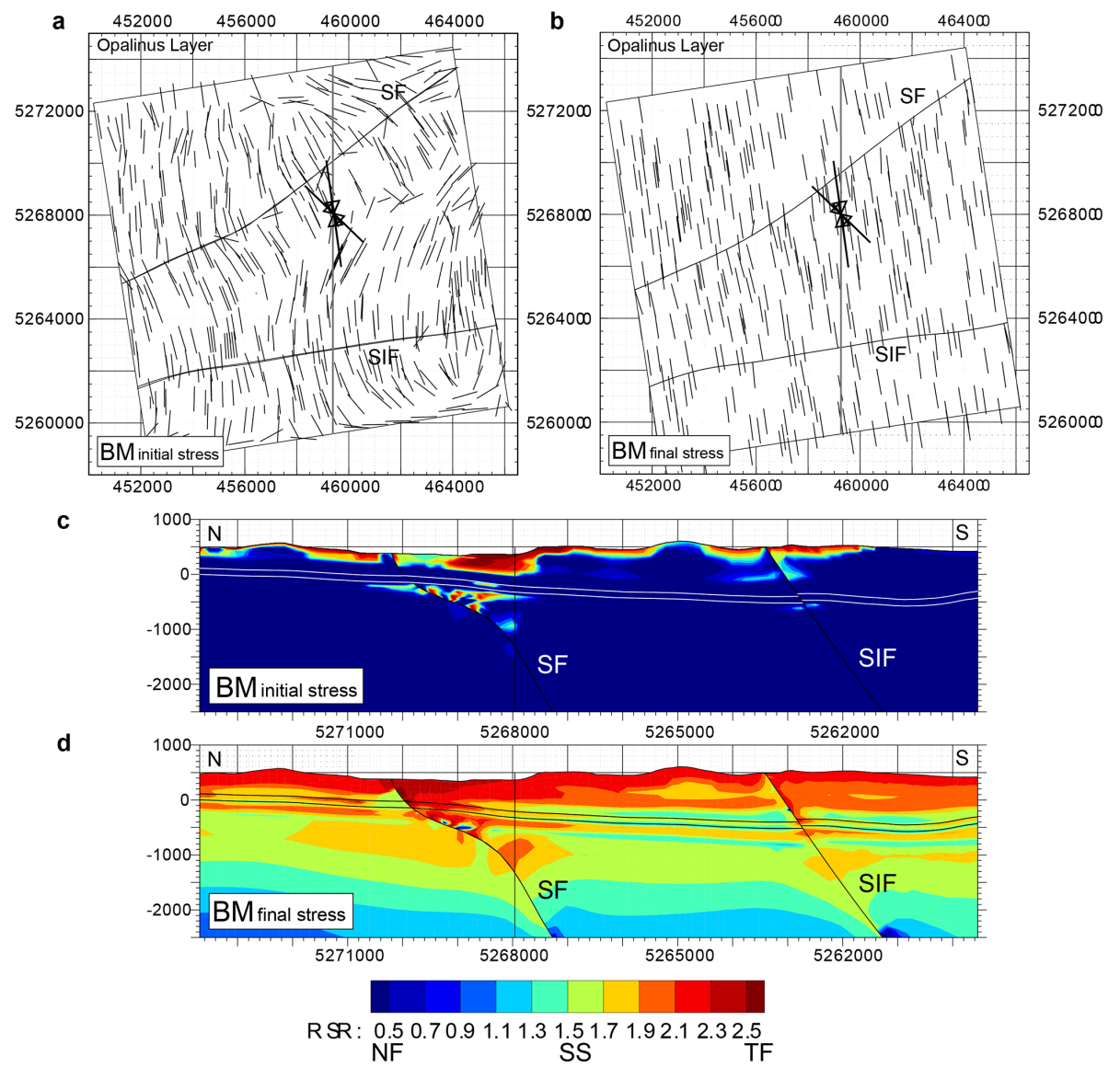

Figure 9. $S_{\mathrm{H}}$ orientation and tectonic regime. (a) $S_{\mathrm{H}}$ orientation at mid-depth of the Opalinus Clay layer for the initial stress field of model BM. Thin black lines show the modelled $S_{\mathrm{H}}$ orientations and the two thick black lines the $S_{\mathrm{H}}$ orientation derived at two depth levels at the Weiach well by Heidbach and Reinecker (2013) (see also Fig. 1). Thin north-south oriented line denotes location of the cross sections in (c) and (d). (b) Same as (a) but for final stress field of model BM after applying tectonic loading. (c) Tectonic regime in terms of regime stress ratio (RSR) on a north-south cross section through the Weiach well for the initial stress field of model BM. The RSR provides a continuous range of the tectonic regime: NF, normal faulting; SS, strike-slip; TF, thrust faulting. (d) As in (c), but for the final stress state of model BM. The south-dipping Opalinus Clay is indicated by thin black and white lines, respectively.

the $K$ ratio increases due to the horizontal tectonic stresses imposed by the boundary conditions.

\section{Results of the base model}

\subsection{Displacement field}

The SF shows left-lateral offset that increases towards the surface, while the SIF shows right-lateral offset (Fig. 10). This means extrusion of the block in between the SF and the SIF to the east, relative to the adjacent blocks in the north and south. Horizontal slip correlates with dip of the SF, i.e. large offset at steep portions of the fault and small offset at low-angle dip. The SF and SIF show thrust faulting and thereby accommodate N-S shortening (Fig. 10). Uplift occurs throughout the whole model area due to the push from the south. Uplift increases towards the surface, but also piecewise from the southern model boundary towards the SIF, from the SIF to the SF and from the SF to the northern model boundary (Fig. 10). Note that the modelled amount of displacements does not mean total displacement during the geological past. Displacements within the model area can be understood in relation to the amount of displacement at the model boundary. If an assumption were to be made of what period of time the displacements at the model boundaries would occur one would get displacement rates.

\subsection{Differential stresses}

The competent formations Upper Malm and Middle Muschelkalk are clearly characterized by increased differential stress $S_{1}-S_{3}$ of up to $20 \mathrm{MPa}$ compared to low values in the weaker formations, mostly 4-7 MPa in the Opalinus Clay (Fig. 11). The vertical changes of differential stress are therefore very pronounced (factor of about 4 ), whereas 

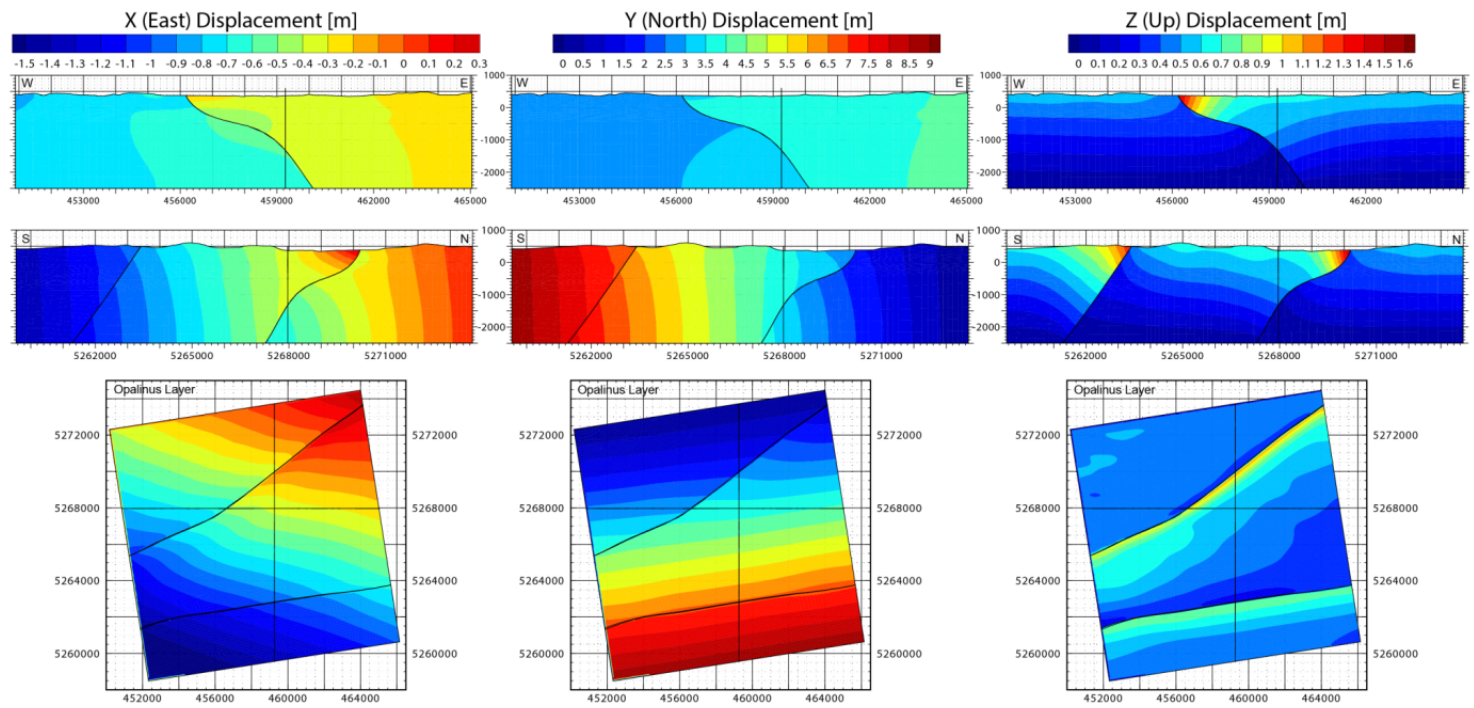

Figure 10. Displacements. EW (left column), NS (middle column) and vertical displacements (right column) in vertical EW (top row) and NS (middle row) profiles through the Weiach well and at the mid-depth of the Opalinus Clay (bottom row). Thin lines denote the location of the profiles.

within a formation differential stress is rather uniform (factor of about 2 at most), at least within the deeper formations (Fig. 11). Similarly, the horizontal differential stress $S_{\mathrm{H}}-S_{\mathrm{h}}$ is about $3-6 \mathrm{MPa}$ in the Opalinus Clay.

\subsection{Stress ratio}

The ratio $S_{\mathrm{H}} / S_{\mathrm{h}}$ ranges between 1.2 and 1.4 in the Opalinus Clay, except in the NW, where it is higher (Fig. 12 top). In the other (stiffer) formations $S_{\mathrm{H}} / S_{\mathrm{h}}$ is clearly higher. Furthermore, $S_{\mathrm{H}} / S_{\mathrm{h}}$ generally increases towards the surface.

The ratio $S_{\mathrm{H}} / S_{\mathrm{V}}$ exhibits very high values $>2$ in the uppermost Molasse formation but strongly decreases to 1.5 and less below the Upper Malm (Fig. 12 middle). The ratio $S_{\mathrm{H}} / S_{\mathrm{V}}$ is about 1 at the base of the model, thus also the ratio $S_{\mathrm{H}} / S_{\mathrm{V}}$ generally increases towards the surface. In the Opalinus Clay $S_{\mathrm{H}} / S_{\mathrm{V}}$ ranges between about 1.1 and 1.3 in most of the model area, with an increase to $>1.3$ in a narrow stretch of 1-2 km width south of the SF and north of it (Fig. 12 middle).

The ratio $S_{\mathrm{h}} / S_{\mathrm{V}}$ varies between 0.8 and 1.1 in the Opalinus Clay and is slightly less than 1 in most of the model area (Fig. 12 bottom). Also $S_{\mathrm{h}} / S_{\mathrm{V}}$ increases towards the $\mathrm{SF}$ and towards the surface. However, differences in $S_{\mathrm{h}} / S_{\mathrm{V}}$ among the individual Mesozoic formations are smaller than for $S_{\mathrm{H}} / S_{\mathrm{h}}$ and $S_{\mathrm{H}} / S_{\mathrm{V}}$. All stress ratios $S_{\mathrm{H}} / S_{\mathrm{h}}, S_{\mathrm{H}} / S_{\mathrm{V}}$ and $S_{\mathrm{h}} / S_{\mathrm{V}}$ show reduced values within the Opalinus Clay compared to the stiffer formations above and below (Fig. 12). Further, all stress ratios tend to increase beneath topographic depressions, e.g. below the Rhine valley.
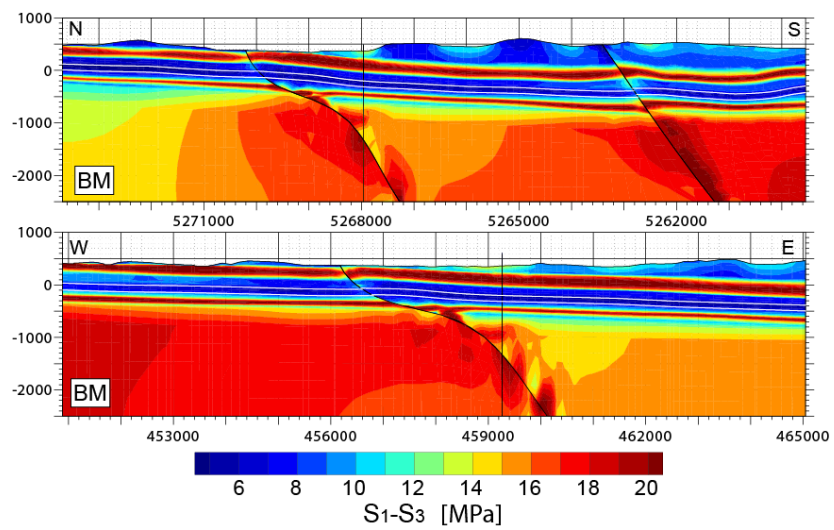

Figure 11. Differential stress $S_{1}-S_{3}$ in the base model BM along north-south and west-east cross sections through the Weiach well. Thin white lines indicate top and bottom of the Opalinus Clay.

\section{Results of model variants}

In this section the results of the model variants regarding rock properties as well as fault geometry and fault friction are presented. The changes in these model variants with respect to model BM are listed in Table 2.

\subsection{Influence of topography}

To investigate the influence of topography, a model with homogeneous mechanical properties (E0 in Table 2) is considered. In such a model, the effect of topography is not concealed by the influence of the different rock properties of the individual formations. The pattern of the topography (see Fig. 2) is reflected in the initial $S_{\mathrm{H}}$ magnitudes (i.e. without 

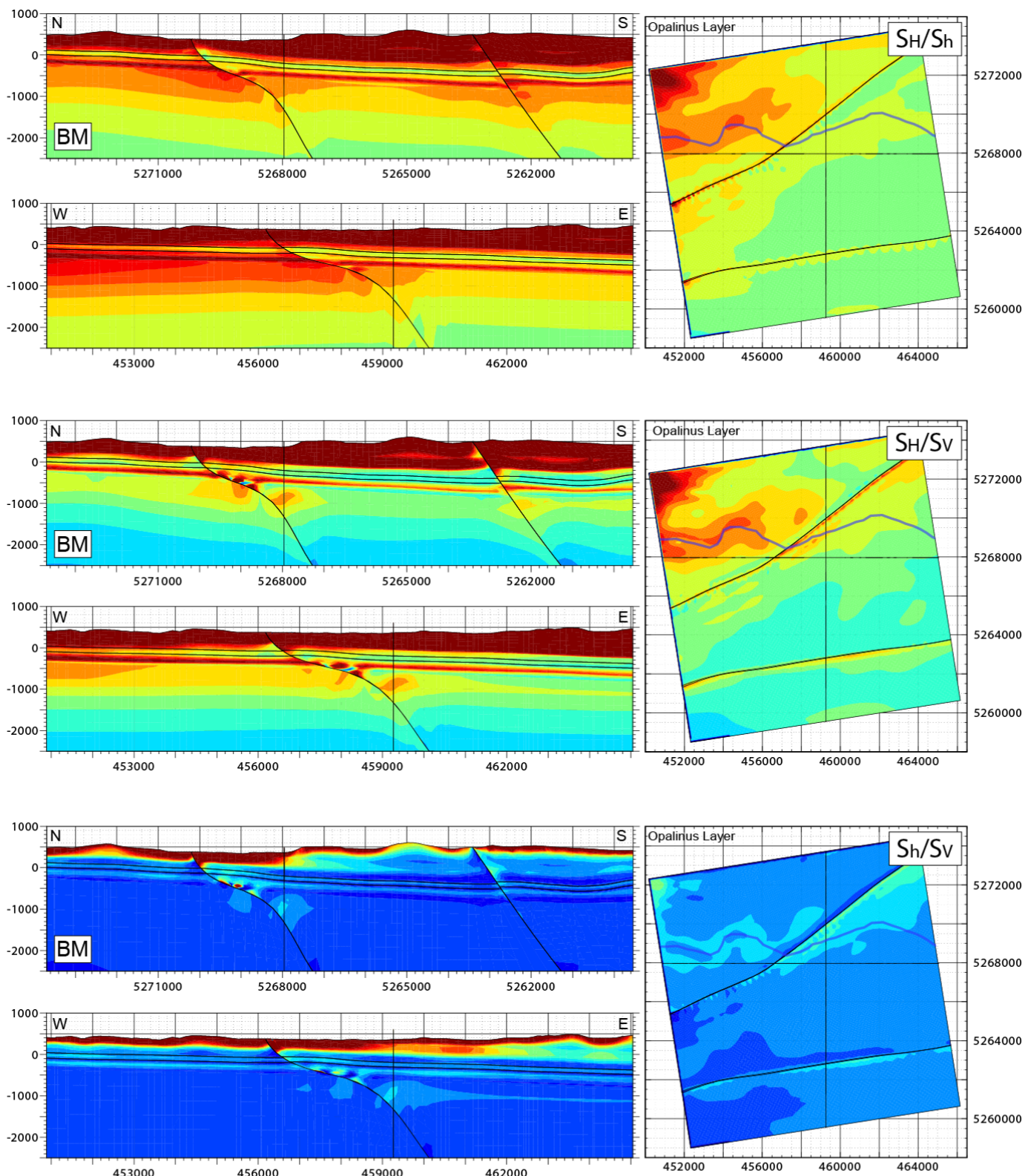

$0.50 .60 .70 .80 .9 \quad 1 \quad 1.111 .21 .31 .41 .51 .61 .71 .81 .92$

Figure 12. Stress ratios $S_{\mathrm{H}} / S_{\mathrm{h}}$ (top), $S_{\mathrm{H}} / S_{\mathrm{V}}$ (middle) and $S_{\mathrm{h}} / S_{\mathrm{V}}$ (bottom) in north-south and east-west cross sections through the Weiach well (left) and at mid-depth of the Opalinus Clay formation (right). Colour scale is the same for all figures. Thin lines denote location of cross sections, faults and top and bottom of the Opalinus Clay formation. Blue line on the map views on the right indicates the location of the Rhine River.

displacement boundary conditions) with higher values below elevated areas and relatively low values below topographic depressions (Fig. 13, left column). Gradients of topography become much more expressed once tectonic boundary conditions are applied (Fig. 13, right column). In this case $S_{\mathrm{H}}$ corresponds roughly to the north-south component of stress. The stress magnitude $S_{\mathrm{H}}$ is increased below valleys, particularly below east-west elongated ones, while stress is reduced below ridges. The topographical influence on stress can be traced down to several hundred metres below surface. Particularly steep slopes of topography are expressed in the stress pattern. The effect from topographic features of small extent disappears at shallower depth than the stress signature from elevation changes of greater lateral extent. 
Table 2. Properties of the model variants (only changes with respect to the base model BM are listed).

\begin{tabular}{llll}
\hline Model & Properties & $\begin{array}{l}\text { Effective friction } \\
\text { coefficient } \mu^{\prime}\end{array}$ & Boundary conditions \\
\hline BM & see Table 1 & 0.2 & NS: $9 \mathrm{~m}$; EW: $-0.8 \mathrm{~m}$ (total E $+\mathrm{W}$ ) \\
\hline E0 & $\begin{array}{l}\rho=2.6 \mathrm{~g} \mathrm{~cm}^{-3}, \nu=0.26, \\
E=25 \mathrm{GPa} \text { in all formations }\end{array}$ & & \\
\hline E1 & $\begin{array}{l}\text { Upper Dogger: } E=20 \mathrm{GPa} \\
\text { Lias and Upper Keuper: } E=20 \mathrm{GPa}\end{array}$ & & \\
\hline E2 & $\begin{array}{l}\text { Upper Dogger: } E=20 \mathrm{GP} \\
\text { Lias and Upper Keuper: } E=10 \mathrm{GPa}\end{array}$ & & \\
\hline E3 & Upper Dogger: $E=10 \mathrm{GPa}$ \\
& Lias and Upper Keuper: $\mathrm{E}=20 \mathrm{GPa}$ & & \\
\hline E4 & Upper Dogger: $E=10 \mathrm{GPa}$ & & \\
& Lias and Upper Keuper: $E=10 \mathrm{GPa}$ & & NS: $30 \mathrm{~m} ; \mathrm{EW:}-1.5$ (gradually) \\
\hline G10 & & 1.0 & \\
\hline GB & & 0.2 (sediments), 100 (basement) & \\
\hline GR & & 0.2 (incl. generic back thrust) & \\
\hline P2 & & &
\end{tabular}

\subsection{Influence of rock properties}

An increase or decrease of the Young's modulus for the Keuper and Upper Dogger formations below and above the Opalinus Clay, respectively, has only very small impact on the stress ratios $S_{\mathrm{H}} / S_{\mathrm{h}}, S_{\mathrm{h}} / S_{\mathrm{V}}$ and $S_{\mathrm{H}} / S_{\mathrm{V}}$ in the Opalinus Clay. Increasing the Young's modulus of the Keuper and Upper Dogger by $33 \%$ to $20 \mathrm{GPa}$ results in slightly increased stress ratios in the Opalinus Clay, whereas a smaller Young's modulus of the Keuper and the Upper Dogger (33\% less to $10 \mathrm{GPa}$ ) results in slightly lower stress ratios in the Opalinus Clay. However, changes in stress ratios are always smaller than 0.1. Figure 14 reveals the strong influence of the variable properties of the individual formations on the stress state by comparison of BM with the homogeneous model E0. Plastic rock behaviour does not result in any significant changes of stress ratios compared to an elastic model. This is because the compressive strength of the rock is not reached throughout most of the model volume. Plastic strain only occurs at some locations at the bottom or at the edges of the model and where the edges of the model are intersected by faults.

\subsection{Influence of fault geometry and coefficient of friction}

In model G10 the effective coefficient of friction on the faults is set to $\mu^{\prime}=1.0$ (Table 2). The results (Fig. 15) show an overall increase of the ratios $S_{\mathrm{H}} / S_{\mathrm{h}}$ and $S_{\mathrm{H}} / S_{\mathrm{V}}$, but a decreased ratio of $S_{\mathrm{h}} / S_{\mathrm{V}}$ in the Opalinus Clay. An exception is in the western and southern part of the block between SIF and
$\mathrm{SF}$, where $S_{\mathrm{h}} / S_{\mathrm{V}}$ increases. Changes are smaller than 0.1 in most of the model area and 0.2 south of the SF in the eastern half of the model. From about half a kilometre north of the SF to about $2 \mathrm{~km}$ south of the SF, $S_{\mathrm{H}} / S_{\mathrm{h}}$ increases by about $50 \%$ in the Upper Malm $\left(S_{\mathrm{H}} / S_{\mathrm{h}}\right.$ up to 2.5$)$ compared to BM. The ratio $S_{\mathrm{H}} / S_{\mathrm{h}}$ increases also south of it, although less.

In the model variant GB faults are deactivated below the base of the Middle Muschelkalk by using a very high coefficient of friction $\left(\mu^{\prime}=100\right)$, which means that faults essentially become locked. This reduces the stress ratios $S_{\mathrm{H}} / S_{\mathrm{h}}$, $S_{\mathrm{h}} / S_{\mathrm{V}}$ and $S_{\mathrm{H}} / S_{\mathrm{V}}$ within the Opalinus Clay in most of the model area, particularly immediately south of the SF (Fig. 15). However, changes with respect to BM are smaller than 0.1. Below the Opalinus Clay the stress ratios increase.

Incorporation of a back thrust adjacent to the SF (Model GR in Fig. 15) reduces the horizontal stresses outside the wedge formed by the back thrust and the SF. The decrease of the stress ratios $S_{\mathrm{H}} / S_{\mathrm{h}}, S_{\mathrm{h}} / S_{\mathrm{V}}$ and $S_{\mathrm{H}} / S_{\mathrm{V}}$ within the Opalinus Clay compared to $\mathrm{BM}$ occurs predominantly close to the wedge. The decreased ratios are also found north of the wedge. The uplift of the wedge lowers horizontal stress in the individual formations. In the Opalinus Clay the effect of the back thrust is smaller than at shallower depth because the wedge terminates just below the Opalinus Clay. Particularly, horizontal stress anisotropy is reduced by the back thrust in the Upper Malm south of the SF. 


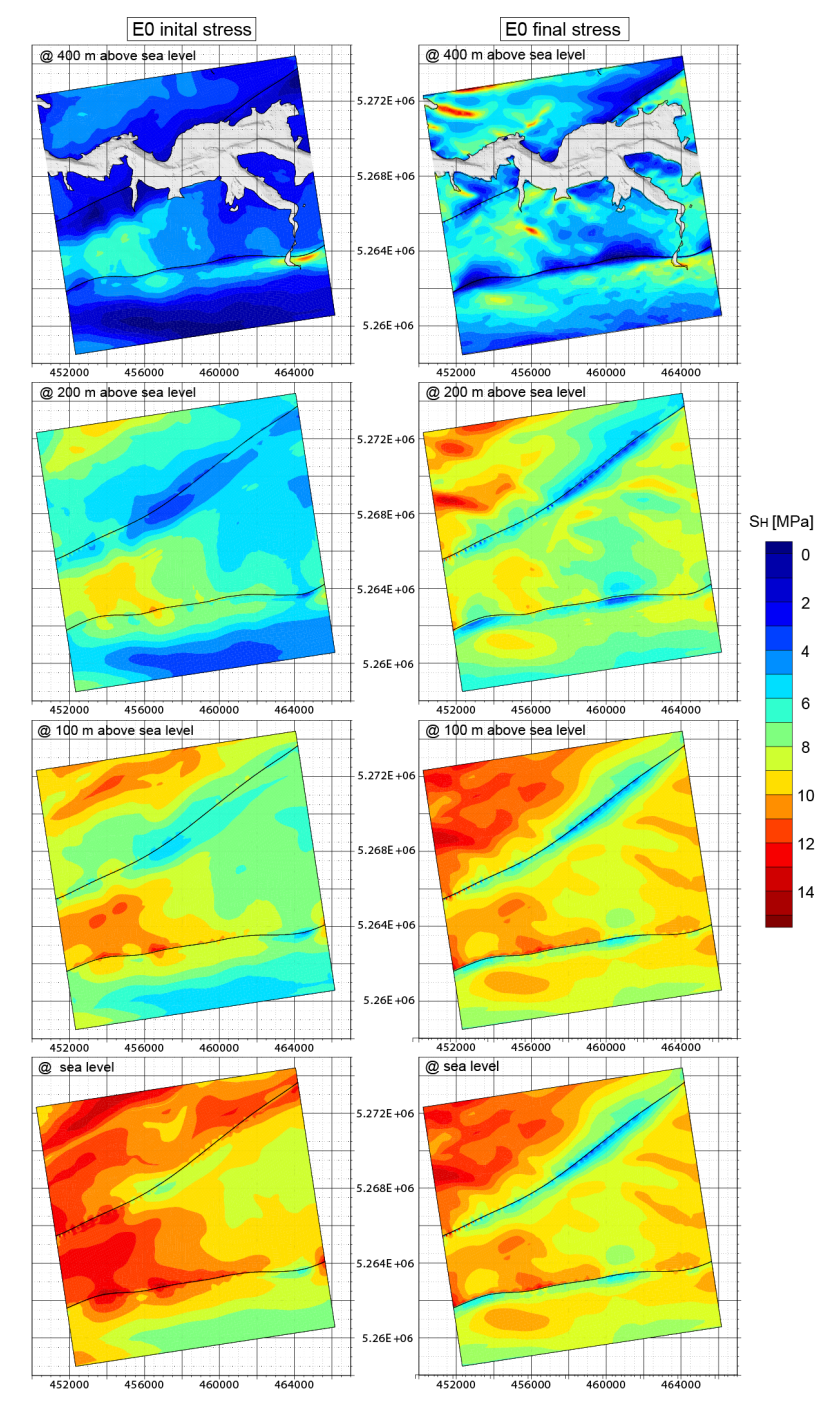

Figure 13. $S_{\mathrm{H}}$ magnitude from the homogeneous model (E0) at different elevations with respect to sea level. Left column without displacement boundary conditions, right column with displacement boundary conditions applied.

\subsection{Plastic limit}

In the previous model runs the southern model boundary was displaced by $9 \mathrm{~m}$ to the north to account for the tectonic boundary conditions, i.e. to generate the desired horizontal in situ stress magnitudes. This rather moderate amount of shortening did not lead to any significant failure of the geomechanical units since the compressive strength is not reached. In this section the effect of further south-north shortening is assessed by starting with model BM and sequentially adding up to $21 \mathrm{~m}$ of additional shortening (total $30 \mathrm{~m}$ ) and allowing for additional extension both at the western and eastern model boundaries up to $1.1 \mathrm{~m}$ each (total $3 \mathrm{~m}$ ). Assuming that the overall south-north shortening between the central Alps and the southern Black Forest north of the geological siting area is between 0.1 and $1 \mathrm{~mm} \mathrm{a}^{-1}$, the south-north shortening within the model area is approximately between 0.01 and $0.1 \mathrm{~mm} \mathrm{a}^{-1}$. Thus, $21 \mathrm{~m}$ of additional shortening may broadly represent a time span between $2.1 \mathrm{Ma}$ and $210 \mathrm{ka}$. The real south-north shorting is still not resolved in the GPS data.

The evolution of differential stress with progressive shortening (left column of Fig. 16) shows that the stiff formations of the Upper Malm and the Upper Muschelkalk bear most of the differential stress accumulation. The maximum values of horizontal differential stress $S_{\mathrm{H}}-S_{\mathrm{h}}$ in the Opalinus Clay is $<20 \mathrm{MPa}$ whereas in the stiffer formations it is partly $>60 \mathrm{MPa}$. In order to assess which of the formations will most likely undergo plastic deformation at additional shortening the fracture potential $\mathrm{FP}=\sigma_{\mathrm{d}} / \sigma_{\mathrm{dcrit}}$ is calculated for each unit using the values for the friction angle and the cohesion given in Table $1\left(\sigma_{\mathrm{d}}\right.$ is the differential stress and $\sigma_{\text {dcrit }}$ the critical differential stress at which the failure envelope is reached). Thus, plastification occurs for $\mathrm{FP} \geq 1$. The results show that this plastic limit is only reached after approximately $15 \mathrm{~m}$ of additional shortening when the FP value reaches values close to or equal to one (right column of Fig. 16). The Molasse sediments and the stiff formations that are close to the surface are most prone to failure. In the Opalinus Clay FP values are below 0.8 except near the SF where FP values are close to one at the final stage of $21 \mathrm{~m}$ additional south-north shortening. The stiff Upper Muschelkalk below the Opalinus Clay has even slightly lower FP values compared to the clay-rich units.

\section{Discussion}

\subsection{Implications of results}

\subsubsection{Role of topography}

As expected, the laterally varying weight of the overburden due to the topography in the model area (Fig. 2) is clearly visible in the model results (Fig. 13 left column). Below mountains stress is increased and vice versa below valleys stress is decreased. However, topography affects the stress state also in an indirect way. The northward-directed horizontal push induces stress that is determined by the shape of the surface. Below valleys the $S_{\mathrm{H}}$ magnitude increases and below mountains stress slightly decreases. Thus, the stress contribution due to the horizontal push is opposite to the imposed lateral stress changes that originate from the weight of the overburden only (Fig. 13). Below valleys $S_{\mathrm{V}}$ is reduced due to the lower weight of the overburden and the horizontal stresses $S_{\mathrm{H}}$ and $S_{\mathrm{h}}$ are increased due to interaction between topography and far field push (see Sect. 4.1). In the north of the model area stress ratios are generally higher in the Opalinus Clay than in the south. This is because stress ratios generally increase towards the surface (Opalinus Clay becomes 


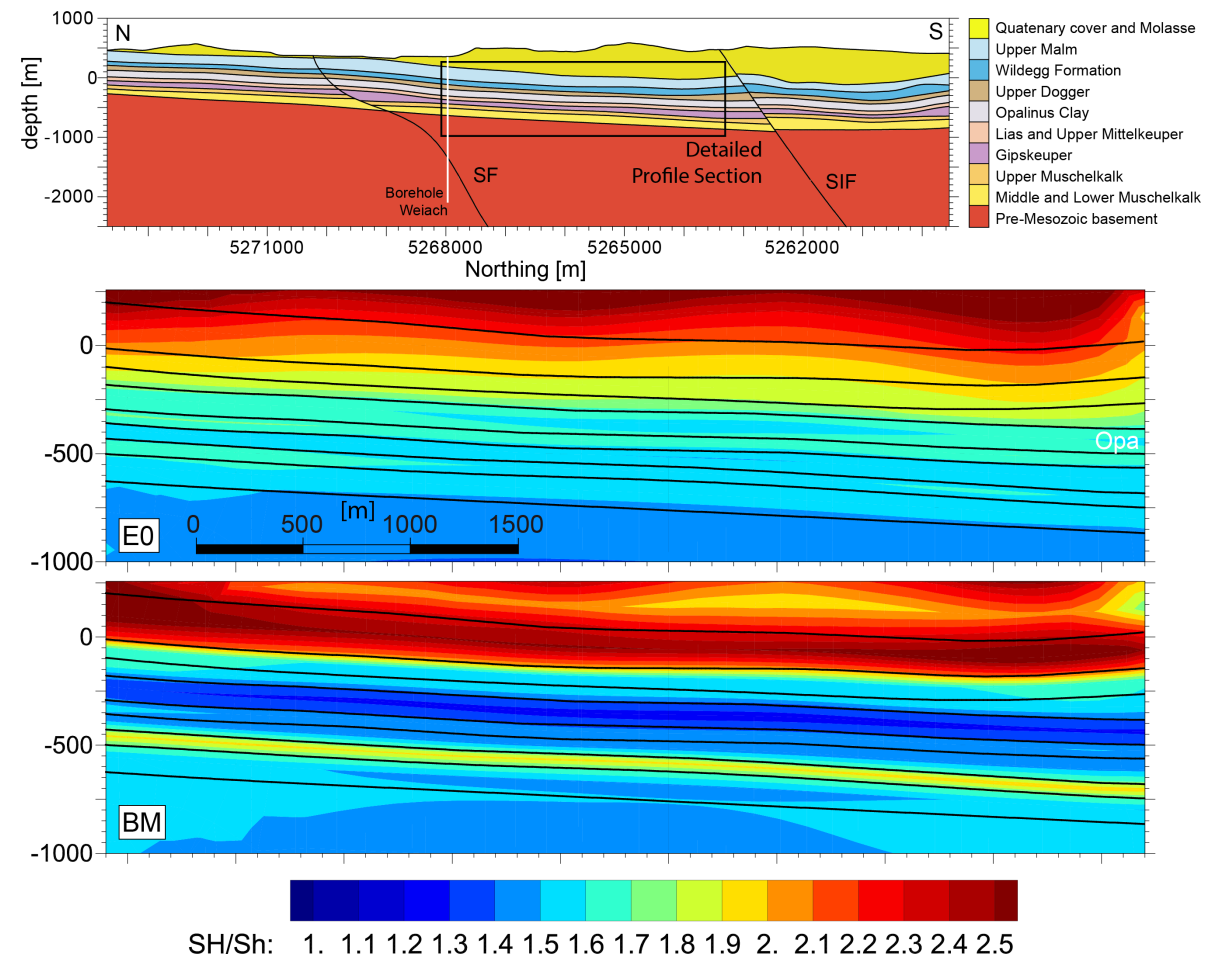

Figure 14. Detailed view of $S_{\mathrm{H}} / S_{\mathrm{h}}$ ratio in north-south cross sections through the Weiach well for different Young's moduli. Geomechanical stratification for reference (top), homogeneous model E0 (middle) and base model BM (bottom) with rock properties as defined in Table 1.

shallower from south to north) since the vertical stress (overburden) vanishes, while the horizontal stresses $S_{\mathrm{H}}$ and $S_{\mathrm{h}}$ do not. The influence of topography on in situ stress state has been predicted or assessed elsewhere (Warpinski and Teufel, 1991; Pan et al., 1995; Griffith et al., 2014).

\subsubsection{Role of individual formations}

Deformation in the model is roughly the same in the individual Mesozoic formations due to the uniformly applied displacement at the southern model boundary over the whole depth extent of the model. In contrast, the tectonic regime and the stress ratios $S_{\mathrm{H}} / S_{\mathrm{h}}, S_{\mathrm{H}} / S_{\mathrm{V}}, S_{\mathrm{h}} / S_{\mathrm{V}}$ as well as the horizontal differential stresses $S_{\mathrm{H}}-S_{\mathrm{h}}$ are much greater in the competent formations than in the weak formations. It is interpreted that the northward-directed horizontal push is carried predominantly by the formations with higher stiffness. The stiff Upper Malm and Middle Muschelkalk formations above and below the argillaceous formations shield those weaker formations, leaving them in a stress shadow. The strong variability of stress over different formations implies that derivation of linear depth gradients of stress based on a few measurements may be misleading.

Moderate stiffness variation of the Upper Dogger and Upper Keuper formations resting above and below the Opalinus Clay affects stress ratios in the Opalinus Clay only marginally. This is because the yet stiffer Upper Malm and Middle Muschelkalk exert a dominant control as loadbearing formations. The very uniform $S_{\mathrm{H}}$ orientation over all formations indicates relatively high horizontal differential stress. This does not imply, however, that there is no stress decoupling active in any of the formations, because the boundary conditions are uniformly applied over the whole depth extent of the model.

Variable stress magnitudes in different formations of a sedimentary sequence have been observed in other areas as well (Burlet and Ouvry, 1989; Evans et al., 1989; Plumb et al., 1991; Wileveau et al., 2007). In the model differential stress is lower and $S_{\mathrm{h}}$ magnitudes are higher in the argillaceous formations compared to the stiffer formations (Figs. 9 and 11). Similarly, in the Paris basin Gunzburger and Cornet (2007) have found $S_{\mathrm{h}}$ magnitudes in a clay formation to be higher than in adjacent stiff limestone units from hydraulic fracturing. Based on a compilation of $S_{\mathrm{h}}$ measurements Plumb (1994) found that whether $S_{\mathrm{h}}$ magnitudes were higher in softer or stiffer formations depends on whether the state of the sedimentary basin is relaxed ( $S_{\mathrm{h}}$ in soft units higher) or compressed ( $S_{\mathrm{h}}$ in stiff units higher). This is qualitatively also reproduced also in Fig. 7f.

\subsubsection{Role of faults on stress}

The role of the semi-generic east-west striking SF and the SIF is revealed by comparing models with different coeffi- 


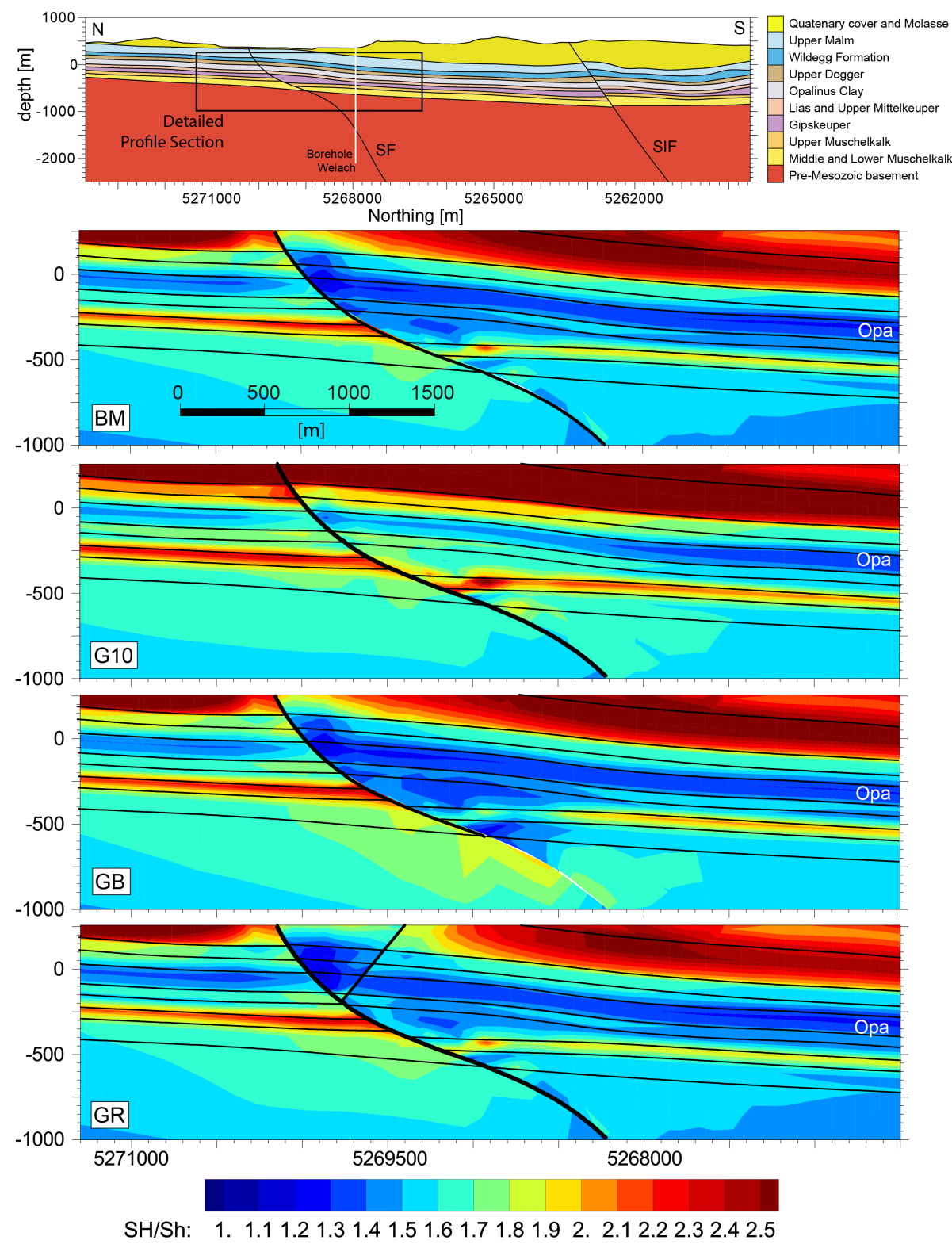

Figure 15. $S_{\mathrm{H}} / S_{\mathrm{h}}$ in north-south cross section through the Weiach well for different fault geometries. BM is the base model, G10 the model with $\mu^{\prime}=1.0 \mathrm{~GB}$ the model where the SF is inactive in the pre-Mesozoic basement and GR the model with a generic back thrust. Box in the upper figure shows location of the sections.

cient of friction on the faults. Infinite friction would mean a fault is absent because a fault's ability to slip is reduced at higher friction. The model with high friction of $\mu^{\prime}=1.0$ (G10) shows higher $S_{\mathrm{H}} / S_{\mathrm{h}}$ ratios in the Mesozoic sediments than BM $\left(\mu^{\prime}=0.2\right)$, particularly in the uppermost $20-300 \mathrm{~m}$ within $2 \mathrm{~km}$ south of the SF. This is an expression of higher horizontal stress anisotropy. Higher stress ratio $S_{\mathrm{H}} / S_{\mathrm{V}}$ and differential stresses at higher fault friction further indicate that the faults reduce the stresses due to the northwarddirected horizontal push within the sedimentary cover.

Several mechanisms can be identified for the reduction of the push and the horizontal stress anisotropy in the Mesozoic formations. First, the faults are reactivated by thrust faulting. The shortening as a result of thrust faulting reduces southnorth-directed compressional stress. Second, the thrust faulting results in vertical offset of the Mesozoic formations at the faults. If a stiff and a soft formation come to lie at opposite sides of the fault, the efficiency of the south-north-directed horizontal push is diminished because the push is governed by the competent formations. And third, the faults are also laterally reactivated. The lateral reactivation of faults, with right-lateral slip on the SIF and left-lateral slip on the SF, results in an eastward-directed extrusion of the block between 

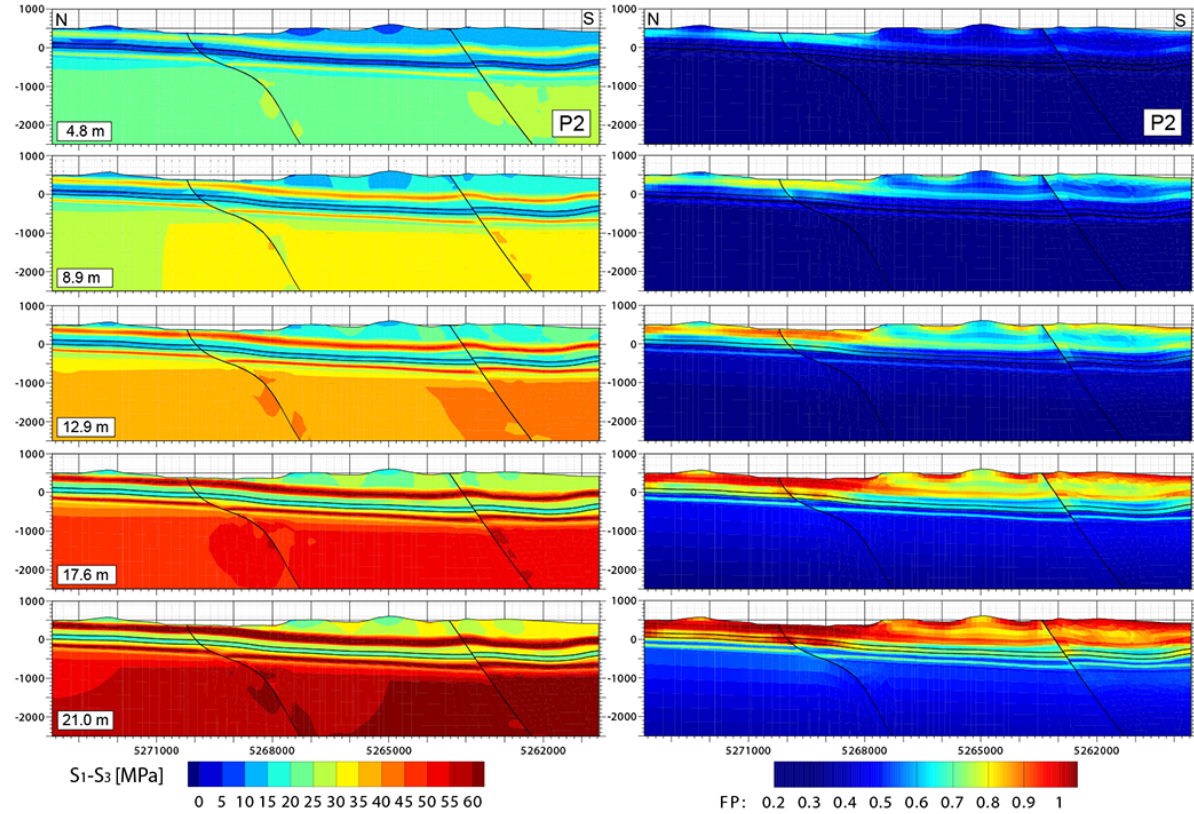

Figure 16. Additional south-north displacement of up to $21 \mathrm{~m}$ (total $30 \mathrm{~m}$ ) and additional east and west displacement of up to $1.1 \mathrm{~m}$ each (total $3 \mathrm{~m}$ ) of model BM in distinct steps displayed on north-south cross sections through the Weiach well. Thin black lines indicate top and bottom of the Opalinus Clay. Left column shows the gradual increase of the differential stress; right column shows the increase of the fracture potential (FP) which is the ratio of the actual differential stress to the yield stress using the plastic properties in each formation as stated in Table 1 . FP values $\geq 1$ indicate plastic failure of the formation.

the SF and the SIF, thereby also weakening the south-northdirected push.

An important question is at what distance from the faults the state of stress can be assumed to be undisturbed by the faults. The role of the faults lowering the overall compression exerted by the horizontal push was outlined already. This effect is appreciable throughout the whole extent of the model. In addition, an area close the faults can be found where the stress is altered by the faults. This near field extends laterally to approximately $1-2 \mathrm{~km}$ from the faults. Generally, the distance at which a fault affects stress in its surrounding depends on the coefficient of friction and total fault displacement as well as on the radius of bends and curvature of the fault (Saucier et al., 1992; Yale, 2003). Stress concentrations, if present, predominantly occur nearby faults and are induced by fault geometry. The implemented generic back thrust reduces horizontal stress anisotropy. However, the influence of the back thrust on the stress is very small at the depth of the Opalinus Clay and increases towards the surface (Fig. 15).

\subsubsection{Pushing the model into the plastic limit}

The stiffer formations essentially carry the load of the far field and, therefore, the stress field of those formations is more sensitive to changes in the boundary conditions than the stress field of the softer formations. This relative difference of stress distributions between stiffer and softer formations is broadly maintained with progressive loading towards the plastic limit. The increase of differential stress in the stiff formations is higher compared to the softer argillaceous formations. However, in terms of fracture potential (FP), the differences are less pronounced. In the deeper stiff formations the FP values are even lower in comparison to the Opalinus Clay (Fig. 16). Due to the high strength of the stiff formations, the deeper stiff formations (e.g. the Lower Muschelkalk) is further away from failure with FP values of approximately 0.5 in the final stage, whereas in the Opalinus Clay FP is approximately 0.7 in the area of the anticipated repository.

The additional south-north shortening of $21 \mathrm{~m}$ in model $\mathrm{P} 2$ alters also the tectonic regime to a compressional stress state. Plastic failure under a compressional tectonic regime would lead to the formation of a thrust fault. Thrust faults tend to propagate towards the surface where the normal stress decreases. Comparably low FP values in the Upper Muschelkalk despite high differential stress makes the generation of a thrust fault propagating through the Opalinus Clay less likely.

\subsection{Validity and limitations of model assumptions}

The presented model includes a number of assumptions and simplifications to maintain practicability and due to sparse subsurface information. These assumptions and simplifications may pose limitations regarding the applicability and reliability of the model.

The model ends north of the Jura main thrust. Therefore, the influence of the geometrical peculiarities of this thrust 
altering the far field push is not considered. Potentially existing Hercynian faults extending from the Black Forest to below the Molasse Basin (Nagra, 2008) are neglected.

Below the Mesozoic sediments, it was assumed that there are uniform PCT sediments down to the model boundary at $2500 \mathrm{~m}$ below sea level. Thus, no distinction is made in the model between crystalline and other pre-Mesozoic basement rocks, although in the Weiach well the contact between PCT sediments and the pre-Mesozoic basement was encountered at $2020 \mathrm{~m}$ depth. The boundaries of the PCT are not known precisely and it is possible that the thickness of the PCT sediments varies strongly over the model area and may even be absent at some locations of the area. However, the impact of this heterogeneity on the stress field in the sediments is probably small compared to the local stiffness variability in the Mesozoic sediments.

The boundaries of the model are rather close to the siting area. Therefore, boundary effects might affect the results. This holds particularly for the boundary conditions at the eastern and western model boundaries at the intersections of the faults with the model boundaries. As the SF and SIF are reactivated left- and right-laterally, respectively, the boundaries should be defined accordingly, allowing fault slip at the boundaries. However, once fault slip is defined at the boundaries, fault slip is no longer an independent result of the model and it is unclear what amount of slip should be imposed. In turn, if no boundary-perpendicular fault slip is allowed at the model boundaries, which is the case for the model presented, an artefact comes into the model as artificial east-west compression is generated at the eastern model boundary south of the SF and extension at the western model boundary south of the SF due to the left-lateral displacement at this fault.

The absence of data on stress magnitudes within the model area limits the reliability of the absolute stresses resulting from the model. The assumption made that the reference stress and the tectonic load are the same in Weiach as in Benken, where stress magnitude data are available, is critical. While at Benken the Mesozoic overlies directly the preMesozoic basement, Weiach is situated over PCT sediments and possibly experiences an influence of the PCT.

Fault geometries used in this study are highly simplified. This is considered appropriate for first-order sensitivity studies. More realistic and complex fault geometries would certainly affect the stress field in the vicinity of fault zones.

Remnant stresses from the geological history are difficult to assess and so are an appropriate initial stress and boundary conditions. The reliability of the model results may be increased if more detailed information on the fault geometries were to be available, if the interface between the PCT sediments and the crystalline basement could be better resolved, if details on the deformation occurring in the area could be determined and most of all if information on stress magnitudes were available in representative formations within the siting area Nördlich Lägern.

\section{Conclusions}

A stress sensitivity analysis using numerical geomechanical modelling was performed to assess the influence of topography, of faults and of mechanical properties on the stress state of a sedimentary sequence in northern Switzerland. The effect of topography on the state field can be attributed predominantly to the interaction between the relief features and the tectonic loading rather than to the gravitational effect alone. Fault structures affect the local stress field as they tend to reduce horizontal stresses from the far field. But the greatest variability in the stress field in the sensitivity study stems from the stiffness contrasts in the sedimentary sequence. The stiffer formations (Upper Malm and Upper Muschelkalk) take up the majority of tectonic stresses associated with the far-field push, while differential stresses remain relatively small in the softer argillaceous formations. Hence the in situ stress field in argillaceous sediments within a stack of formations with strongly contrasting mechanical properties like in the Swiss Alpine foreland basin appears to be relatively insensitive to changes in the tectonic boundary conditions and is largely controlled by the maximum stiffness contrast with respect to the load-bearing formations.

Acknowledgements. This work was supported by the National Cooperative for the Disposal of Radioactive Waste (Nagra), Switzerland. We would like to thank A. Schöpa and H. Madritsch for proof reading and F. Rossetti, F. Beekman and one further reviewer for their comments that improved the paper.

Edited by: F. Rossetti

The article processing charges for this open-access publication were covered by a Research

Centre of the Helmholtz Association.

\section{References}

Altmann, J. B., Müller, B., Müller, T., Heidbach, O., Tingay, M., and Weißhardt, A.: Pore pressure stress coupling in 3D and consequences for reservoir stress states and fault reactivation, Geothermics, 52, 195-205, doi:10.1016/j.geothermics.2014.01.004, 2014.

Barton, C. A. and Zoback, M. D.: Stress perturbations associated with active faults penetrated by boreholes: Possible evidence for near-complete stress drop and a new technique for stress magnitude measurement, J. Geophys. Res., 99, 93739390, doi:10.1029/93JB03359, 1994.

Böhringer, J., Jenni, J. P., Hürlimann, W., Resele, G., Grauer, R., and Norbert J.: Anhydritvorkommen als Wirtgestein für die Lagerung schwach- und mittelaktiver Abfälle dargestellt am Beispiel des Bois de la Glaive: Statusbericht, Nagra Technischer Bericht NTB 88-15, Nagra, Baden, Germany, 1990.

Brooker, E. W. and Ireland, H. O.: Earth Pressures at Rest Related to Stress History, Can. Geotech. J., 2, 1-15, doi:10.1139/t65-001, 1965. 
Burlet, D. and Ouvry, J. F.: In situ stress inhomogeneity in deep sedimentary formations relative to material heterogeneity, Proceedings of Int. Symp. on Rock at Great Depth, Pau, Balkema, Rotterdam, 2, 1065-1071, 1989.

Deichmann, N., Ballarin Dolfin, D., and Kastrup, U.: Seismizität der Nord- und Zentralschweiz, Nagra Tech. Ber. NTB 00-05, p. 113, Nagra, Wettingen, Germany, 2000.

Dassault Systèmes: ABAQUS User Manual (version 6.11), SIMULIA, a division of Dassault Systèmes, Providence, Rhode Island, USA, 2011.

Diebold, P., Naef, H., and Ammann, M.: Zur Tektonik der zentralen Nordschweiz. Interpretation aufgrund regionaler Seismik, Oberflächengeologie und Tiefbohrungen, Geol. Ber. Landeshydrol. u. -geol., 14, 1991.

Diebold, P. and Noack, T.: Late Palaeozoic troughs and Tertiary structures in the eastern Folded Jura, in: Deep Structure of the Swiss Alps: Results of NRP20, edited by: Pfiffner, O. A., Lehner, P., Heitzmann, P., Mueller, S., and Steck, A., Basel, Birkhäuser Verlag, 59-63, 1997.

Evans, K. F., Engelder, T., and Plumb, R. A.: Appalachian stress study, 1. A detailed description of in-situ stress variations in Devonian shale of the Appalachian Plateau, J. Geophys. Res., 94, 7129-7154, 1989.

Fischer, K. and Henk, A.: A workflow for building and calibrating 3-D geomechanical models - a case study for a gas reservoir in the North German Basin, Solid Earth, 4, 347-355, doi:10.5194/se-4-347-2013, 2013.

Fuchs, K. and Müller, B.: World stress map of the Earth: a key to tectonic processes and technological applications, Naturwissenschaften, 88, 357-371, 2001.

Giger, S. and Marschall, P.: Geomechanical properties, rock models and in-situ stress conditions for Opalinus Clay in Northern Switzerland, Nagra Arbeitsber. NAB 14-01, 2014.

Griffith, W. A., Becker, J., Cione, K., Miller, T., Pan, E.: 3-D topographic stress perturbations and implications for ground control in underground coal mines, Int. J. Rock Mech. Min., 70, 59-68, doi:10.1016/j.ijrmms.2014.03.013, 2014.

Gunzburger, Y., Cornet, F. H.: Rheological characterization of a sedimentary formation from a stress profile inversion, Geophys. J. Int., 168, 402-418, doi:10.1111/j.1365-246X.2006.03140.x, 2007.

Gunzburger, Y., and Magnenet, V.: Stress inversion and basementcover stress transmission across weak layers in the Paris basin, France, Tectonophysics, 617, 44-57, 2014.

Heidbach, O. and Reinecker, J.: Analyse des rezenten Spannungsfeldes der Nordschweiz, Nagra Arb. Ber. NAB 12-05, p. 120, Nagra, Wettingen, 2013

Heidbach, O., Reinecker, J., Tingay, M., Müller, B., Sperner, B., Fuchs, K., and Wenzel, F.: Plate boundary forces are not enough: second- and third-order stress patterns highlighted in the world stress map database, Tectonics, 26, TC6014, doi:10.1029/2007TC002133, 2007.

Heidbach, O., Tingay, M., Barth, A., Reinecker, J., Kurfeß, D., and Müller, B.: The World Stress Map database release 2008, available at: http://dc-app3-14.gfz-potsdam.de/pub/introduction/ introduction_frame.html (last access: 5 May 2015), 2008.

Heidbach, O., Tingay, M., Barth, A., Reinecker, J., Kurfeß, D., and Müller, B.: Global crustal stress pattern based on the world stress map database release 2008, Tectonophysics, 482, 3-15, doi:10.1016/j.tecto.2009.07.023, 2010.

Henk, A.: Perspectives of Geomechanical Reservoir Models - Why Stress is Important: European Magazine, 4, 1-5, 2008.

Hergert, T. and Heidbach, O.: Geomechanical model of the Marmara Sea region - II. 3-D contemporary background stress field, Geophys. J. Int., 185, 1090-1102, doi:10.1111/j.1365246X.2011.04992.x, 2011.

Jáky, J.: The coefficient of earth pressure at rest, J. Soc. Hungarian Arch. Eng., 78, 355-358, 1944.

Kempf, O. and Pfiffner, O. A.: Early Tertiary evolution of the North Alpine Foreland Basin of the Swiss Alps and adjoining areas, Basin Res., 16, 549-567, 2004.

Klee, G.: Geothermal borehole Schlattingen 1 - Hydraulic fracturing stress measurements, Nagra Project Report, NPB 12-08, Nagra, Wettingen, Germany, 2012.

Laubscher, H.: Some overall aspects of Jura dynamics, Am. J. Sci., 272, 293-304, 1972.

Laubscher, H.: The eastern Jura-Relations between thin-skinned and basement tec-tonics, local and regional, Geol. Rundschau, Stuttgart, 75, 535-553, 1986.

Madritsch, H., Schmid, S. M., and Fabbri, O.: Interactions between thin- and thick-skinned tectonics at the northwestern front of the Jura fold-and-thrust belt (eastern France), Tectonics, 27, TC5005, doi:10.1029/2008TC002282, 2008.

Malz, A.: Inversionsstrukturen und abgescherte Überschiebungssysteme, Strukurinventar und strukturelle Analyse einengender Deformation in Mitteleuropa am Beispiel der Thüringer Mulde und des Schweizer Faltenjura, $\mathrm{PhD}$ thesis, Geologisches Institut, Universität Jena, Germany, 2014.

Malz, A., Madritsch, H., Meier, B., Heuberger, S., and Kley, J.: An unusual triangle structure associated with thrust front developement in the thin-skinned Eastern Jura Mountains, Geophys. Res. Abstracts, 16, EGU2014-15153, 2014.

Matter, A., Peters, T., Bläsi, H. R., Meyer, J., Ischi, H., and Meyer, C.: Sondierbohrung Weiach Geologie: Textband, Nagra Technischer Bericht, NTB 86-01, Nagra, Baden, Germany, 1988.

Mayne, P. W. and Kulhawy, F. H.: Ko-OCR relationships in soil, J. Geotech. Eng.-ASCE, 108, 6, 851-872, 1982.

Mazurek, M., Hurford, A. J., and Leu, W.: Unravelling the multistage buriel history of the Swiss Molasse basin: integration of apatite fission track, vitrinite reflectance and biomarker isomerisation analysis, Basin Res., 18, 27-50, 2006.

Moeck, I., Kwiatek, G., and Zimmermann, G.: Slip tendency analysis, fault reactivation potential and induced seismicity in a deep geothermal reservoir, J. Struct. Geol., 31, 1174-1182, doi:10.1016/j.jsg.2009.06.012, 2009.

Nagra: Sondierbohrung Benken: Hydrofrac Spannungsmessungen. Teil I: Auswertung der Feldmessungen, Nagra Int. Ber. NIB 9936a, p. 100, Nagra, Wettingen, Germany, 1999.

Nagra: Sondierbohrung Benken Untersuchungsbericht, Nagra Tech. Ber. NTB 00-01, p. 273, Nagra, Wettingen, Germany, 2001.

Nagra: Vorschlag geologischer Standortgebiete für das SMA- und das HAA-Lager, Nagra Tech. Ber. NTB 08-04, p. 395, Nagra, Wettingen, Germany, 2008.

Nagra: SGT Etappe 2: Vorschlag weiter zu untersuchender geologischer Standortgebiete mit zugehörigen Standortarealen für die Oberflächenanlage. Geologische Grundlagen, Dossier II. Nagra Tech. Ber. NTB 14-02, 2014a. 
Nagra: SGT Etappe 2: Vorschlag weiter zu untersuchender geologischer Standortgebiete mit zugehörigen Standortarealen für die Oberflächenanlage. Geologische Grundlagen, Dossier IV. Nagra Tech. Ber. NTB 14-02, 2014b.

Pan, E., Amadei, B., and Savage, W. Z.: Gravitational and tectonic stresses in anisotropic rock with irregular topography, Int. J. Rock Mech. Min., 32, 201-214, 1995.

Plumb, R. A.: Variations of the least horizontal stress magnitude in sedimentary rocks, in: Proc. 1st North Amer. Rock Mech. Symp., Austin, Balkema, Rotterdam, 71-78, 1994.

Plumb, R. A., Evans, K. F., and Engelder, T.: Geophysikal log responses and their correlation with bed-to-bed stress contrasts in Paleozoic rocks, Appalachian Plateau, NY, J. Geophys. Res., 96, 14509-14528, 1991.

Reinecker, J., Tingay, M., Müller, B., and Heidbach, O.: Present-day stress orientation in the Molasse Basin, Tectonophysics, 462, 14, doi:10.1016/j.tecto.2009.1007.1021, 2010.

Reiter, K. and Heidbach, O.: 3-D geomechanical-numerical model of the contemporary crustal stress state in the Alberta Basin (Canada), Solid Earth, 5, 1123-1149, doi:10.5194/se-5-11232014, 2014.

Roche, V., Homberg, C., and Rocher, M.: Fault nucleation, restriction, and aspect ratio in layered sections: quantification of the strength and stiffness roles using numerical modeling, J. Geophys. Res., 118, 1-15, doi:10.1002/jgrb.50279, 2013.

Saucier, F., Humphreys, E., and Weldon, R.: Stress near geometrically complex strike-slip faults: application to the San Andreas Fault at Cajon Pass, southern California, J. Geophys. Res., 97, 5081-5094, doi:10.1029/91JB02644, 1992.

Savage, W. Z. and Morin, R. H.: Topographic stress perturbations in southern Davis Mountains, west Texas 1. Polarity reversal of principal stresses, J. Geophys. Res., 107, 2339, doi:10.1029/2001JB000484, 2002.

Schmid, S. M., Pfiffner, O. A., Froitzheim, N., Schönborn, G., and Kissling, E.: Geophysical-geological transect and tectonic evolution of the Swiss-Italian Alps, Tectonics, 15, 1036-1064, 1996.

Simpson, R. W.: Quantifying Anderson's fault types, J. Geophys. Res., 102, 17909-17919, 1997.

Sinclair, H. and Allen, P. A.: Vertical versus horizontal motions in the Alpine orogenic wedge: stratigraphic response in the Foreland Basin, Basin Res., 4, 215-232, 1992.
Sommaruga, A.: Geology of the central Jura and the Molasse Basin: new insight into an evaporite-based foreland fold and thrust belt, Mem. Soc. Sci. nat. Neuchatel, 12, 716 pp., 1997.

Sperner, B., Müller, B., Heidbach, O., Delvaux, D., Reinecker, J., and Fuchs, K.: Tectonic stress in the Earth's crust: advances in the world stress map project, in: New Insights in Structural Interpretation and Modelling, Volume 212, edited by: Nieuwland, D. A., Geological Society, London, 101-116, 2003.

Tingay, M., Müller, B., Reinecker, J., Heidbach, O., Wenzel, F., and Fleckenstein, P.: Understanding Tectonic Stress in the Oil Patch: The World Stress Map Project, The Leading Edge, 1276-1282, 2005.

Ustaszewski, K. and Schmid, S. M.: Latest Pliocene to recent thickskinned tectonics at the Upper Rhine Graben - Jura Mountains junction, Swiss J. Geosci., 100, 293-312, 2007.

Valley, B. and Evans, K. F.: Estimation of the stress magnitudes in Basel enhanced geothermal system, in: Proceedings World Geothermal Congress, Melbourne, Australia, 19-25 April 2015, 2015.

Warpinski, N. R.: Determining the minimum in situ stress from hydraulic fracturing through perforations, Int. J. Rock Mech. Min., 26, 523-531, 1989.

Warpinski, N. R. and Teufel, L. W.: In-situ stress measurements at Rainier Mesa, Nevada Test Site - influence of topography and lithology on the stress state in tuff, Int. J. Rock Mech. Min., 28, 143-161, 1991.

Wileveau, Y., Cornet, F. H., Desroches, J., and Blumling, P.: Complete in situ stress determination in an argillite sedimentary formation, Phys. Chem. Earth, 32, 866-878, 2007.

Yale, D. P.: Fault and stress magnitude controls on variations in the orientation of in situ stress, Geol. Soc. Spec. Publ., 209, 55-64, doi:10.1144/GSL.SP.2003.209.01.06, 2003.

Ziegler, P. and Dèzes, P.: Crustal evolution of Western and Central Europe, in: European Lithosphere Dynamics, Volume 32, edited by: Gee, D. G. and Stephenson, R. A., Geol. Soc. Mem., London, 32, 43-56, 2006.

Zoback, M.: Reservoir Geomechanics, Cambridge, Cambridge, UK, 449 pp., 2010.

Zoback, M. L.: First and second order patterns of stress in the lithosphere: the world stress map project, J. Geophys. Res., 97, 11703-11728, 1992. 